\title{
Tomentodione $M$ sensitizes multidrug resistant cancer cells by decreasing P-glycoprotein via inhibition of p38 MAPK signaling
}

\author{
Xu-Wei Zhou ${ }^{1, *}$, Yuan-Zheng Xia ${ }^{1, *}$, Ya-Long Zhang ${ }^{1}$, Jian-Guang Luo ${ }^{1}$, Chao Han ${ }^{1}$, \\ Hao Zhang ${ }^{1}$, Chao Zhang ${ }^{1}$, Lei Yang ${ }^{1}$ and Ling-Yi Kong ${ }^{1}$ \\ 'Jiangsu Key Laboratory of Bioactive Natural Product Research and State Key Laboratory of Natural Medicines, China \\ Pharmaceutical University, Nanjing 210009, China \\ *These authors have contributed equally to this work \\ Correspondence to: Lei Yang, email: dorothy19802003@gmail.com \\ Ling-Yi Kong, email: cpu_lykong@126.com \\ Keywords: tomentodione M; meroterpenoid; multidrug resistance; P-glycoprotein; p38 \\ Received: July 02, $2017 \quad$ Accepted: October 03, $2017 \quad$ Published: October 19, 2017 \\ Copyright: Zhou et al. This is an open-access article distributed under the terms of the Creative Commons Attribution License 3.0 \\ (CC BY 3.0), which permits unrestricted use, distribution, and reproduction in any medium, provided the original author and source \\ are credited.
}

\section{ABSTRACT}

In this study, we investigated the mechanism by which tomentodione M (TTM), a novel natural syncarpic acid-conjugated monoterpene, reversed multi-drug resistance (MDR) in cancer cells. TTM increased the cytotoxicity of chemotherapeutic drugs such as docetaxel and doxorubicin in MCF-7/MDR and K562/MDR cells in a dose- and time-dependent manner. TTM reduced colony formation and enhanced apoptosis in docetaxel-treated MCF-7/MDR and K562/MDR cells, and it enhanced intracellular accumulation of doxorubicin and rhodamine 123 in MDR cancer cells by reducing drug efflux mediated by P-gp. TTM decreased expression of both P-gp mRNA and protein by inhibiting p38 MAPK signaling. Similarly, the p38 MAPK inhibitor SB203580 reversed MDR in cancer cells by decreasing P-gp expression. Conversely, p38 MAPKoverexpressing MCF-7 and $\mathrm{K} 562$ cells showed higher P-gp expression than controls. These observations indicate that TTM reverses MDR in cancer cells by decreasing P-gp expression via p38 MAPK inhibition.

\section{INTRODUCTION}

Multidrug resistance (MDR) is the phenomenon by which neoplastic cells display resistance to many chemotherapeutic drugs that are chemically dissimilar with different cytotoxic targets [1]. MDR negates the efficacy of cancer chemotherapy and results in therapeutic failure, which is detrimental for patient survival. Hence, MDR is the biggest challenge for strong and effective cancer treatment.

Currently, numerous chemotherapeutics are used in the clinic for cancer treatment such as doxorubicin (DOX), Daunorubicin (DNR), Epirubicin (EPI), Docetaxel (Doc) and Cisplatin (DDP) [2]. However, intrinsic or acquired drug resistance such as MDR leads to failure of chemotherapy. In most cases, chemotherapy becomes ineffective over time because of resistance. Moreover, the acquired resistance of the neoplastic cells is not limited to the original drug, but, also affects a wide variety of structurally and mechanistically unrelated drugs. Therefore, new therapeutic strategies are needed to overcome chemotherapy resistance in MDR cancer cells.

The mechanisms underlying MDR in cancer cells are complicated and not completely understood. Some of the MDR-related mechanisms include decreased drug accumulation, alterations in cell cycle checkpoints, resistance to cellular apoptotic mechanisms and repair of damaged cellular targets [3]. The most common and well studied mechanism of MDR in cancer cells is over-expression of ATP-binding cassette (ABC) transporters, whose regulation is highly complex and results in decreased drug accumulation $[4,5]$. The most extensively studied MDR transporters include $\mathrm{ABCB} 1$ (also known as MDR1 or P-gp), ABCC1 (also known as MRP1) and ABCG2 (also known as BCRP or MXR). $\mathrm{ABCA} 1$ was originally found as the primary gatekeeper 
for eliminating cholesterol that played an important role in protecting against cardiovascular disease [6]. It has also been implicated in multi-drug resistance apart from its role in reverse cholesterol metabolism [7, 8]. Moreover, many groups have reported $\mathrm{P}$-gp as a target for antitumor therapy in drug-resistant tumors [9-11].

To date, P-gp is the best studied among the ABCtransporter-mediated MDR proteins [12-14]. The hallmark of chemo-resistance in cancer cells is P-gp overexpression. High P-gp levels are associated with poor survival rate in osteosarcoma [15], lymphomas [16], small-cell lung cancer [17], breast cancer [18] and leukemias [19]. Therefore, P-gp inhibitors are necessary to treat cancer patients that demonstrate MDR. Many P-gp inhibitors such as Valspoder (PSC-833), dofequidar fumarate (MS-209), thiosemicarbazone derivative (NSC73306) Zosuduidar (LY335979) and Tariquidar (XR9567) have been found to antagonize P-gp function [20-23]. However, phase III trials of these drugs have been disappointing, primarily because of low host tolerance to these experimental MDR modulators that precludes the attainment of active intracellular levels [24, 25]. Moreover, these drugs demonstrate adverse effects in patients and alter the pharmacokinetics of co-administered anticancer drug [26]. Also, none of these inhibitors have achieved significant survival benefits [27]. Therefore, there is an urgent need for novel MDR antagonists that demonstrate low toxicity and high efficacy.

Traditional Chinese Medicine (TCM) has offered many alternative natural products that demonstrate great potential as MDR inhibitors with low adverse effects. These natural products decrease P-gp expression [21, 28, 29]. Recent studies have shown that natural terpenoids reverse MDR in cancer cells [30, 31]. However, their mechanism of action is unknown. Therefore, in this study, we investigated the mechanism of action of a novel meroterpenoid, tomentodione $\mathrm{M}$ (TTM) (Figure 1A) in reversing MDR in MCF-7 and K562 cancer cells.

\section{RESULTS}

\section{MDR cancer cells overexpress P-gp}

We first evaluated the cytotoxicity of several anticancer agents such as DOX, DNR, EPI, DDP and Doc in MDR and parental MCF-7 and K562 cell lines. As shown in Table 1, the MCF-7/MDR and K562/MDR cells showed higher $\mathrm{IC}_{50}$ for DOX, DNR, EPI and Doc than the parental MCF-7 and K562 cells, thereby demonstrating drug resistance. However, the $\mathrm{IC}_{50}$ values for DDP were similar in the parental and MDR MCF-7 and K562 cell lines. The resistance index for DOX, DNR, EPI and Doc was 16.60, 29.25, 29.94 and 22.55 in MCF-7/MDR cells, and 181, $72.85,2664.65$ and 7571.1 in K562/MDR cells (Table 1).

Since overexpression of $\mathrm{ABC}$ transporters is the primary determinant of the MDR phenotype, we examined the expression of three main $\mathrm{ABC}$ transporters, $M D R 1, M R P 1$ and $B C R P$ by qRT-PCR. As shown in Figure 1B, $M D R 1$ mRNA was highly expressed in MCF7/MDR and K562/MDR cells than the corresponding parental cells. However, MRP1 or BCRP mRNA levels were similar in both MDR and parental MCF-7 and K562 cells (Figure 1B).

The chemotherapy agents including DOX, DNR, EPI and Doc are exported out of the cells by P-gp [3234]. Therefore, we examined the levels of P-gp protein in MDR and parental MCF-7 and K562 cells. Our data showed high P-gp protein levels in MCF-7/MDR and K562/MDR cells than the corresponding parental cells (Figure 1C) and was consistent with the previous study $[35,36]$. Therefore, we selected MCF-7/MDR and K562/ MDR cells to investigate if TTM reversed P-gp-mediated MDR.

\section{TTM is not cytotoxic to MDR cancer cells and non-tumor cells}

We determined cytotoxicity of TTM on MDR and parental MCF and K562 cells by MTT and Cell Counting Kit-8 (CCK-8) assays. We observed that TTM concentrations below $100 \mu \mathrm{M}$ did not significantly inhibit proliferation of MDR and parental MCF and K562 cells (Figure 1D and 1E). Moreover, treatment with 0-100 $\mu \mathrm{M}$ TTM did not affect cell survival in MDR and parental MCF-7 and K562 cells between 0-48 hrr (Figure 1D and $1 \mathrm{E})$. We also showed that $0-100 \mu \mathrm{M}$ TTM showed no cytotoxicity on non-cancer human mammary epithelial MCF-10A cells at $48 \mathrm{hr}$ (Figure 1F). Therefore, we selected $10 \mu \mathrm{M}$ and $30 \mu \mathrm{M}$ TTM for further experiments since they showed minimal growth inhibition of $<5 \%$ and $<10 \%$, respectively.

\section{TTM reverses $\mathrm{P}$-gp-mediated MDR in vitro}

We investigated if TTM treatment enhanced chemosensitivity of MDR cells to anticancer drugs such as DOX, DNR, EPI, Doc and DDP. We used Verapamil, a P-gp inhibitor and calcium channel blocker as a positive control [37-39]. TTM decreased the drug resistance in MDR cells in a dose-dependent manner. As shown in Table 1, $\mathrm{IC}_{50}$ for DOX, DNR, EPI and Doc decreased by 7.26-, 2.81-, 3.68-, 18.04-fold for MCF-7/MDR and 5.76-, 32.68-, 47.21-, 65.10-fold for K562/MDR cells, when treated with $30 \mu \mathrm{M}$ TTM. On the other hand, $\mathrm{IC}_{50}$ for DOX, DNR, EPI and Doc decreased by 2.39-, 1.42-, 1.77-, 3.79-fold for MCF-7/MDR and 3.38-, 3.04-, 11.97-, 38.45 -fold for K562/MDR, when treated with $10 \mu \mathrm{M}$ TTM. Moreover, TTM treatment did not change the $\mathrm{IC}_{50}$ values of DOX, DNR, EPI, Doc and DDP in the parental MCF-7 and K562 cells (Table 1). These results indicate that TTM reverses P-gp mediated MDR for DOX, DNR, EPI and Doc. 
Table 1: Effect of TTM on cytotoxicity of chemotherapeutic drugs in parental and multi-drug resistant MCF-7 and K562 cells

\begin{tabular}{|c|c|c|c|c|}
\hline \multirow{2}{*}{ Drug } & \multicolumn{4}{|c|}{$\mathrm{IC}_{50} \pm \mathrm{SEM}^{\mathrm{a}}(\boldsymbol{\mu M})(\text { reversal fold change }(\mathrm{RF}))^{\mathrm{b}}$} \\
\hline & MCF-7 & MCF-7/MDR & K562 & K562/MDR \\
\hline Doxorubicin & $\begin{array}{c}0.632 \pm 0.083 \\
\quad(1.00)\end{array}$ & $\begin{array}{c}16.597 \pm 5.225 \\
(1.00)\end{array}$ & $\begin{array}{c}0.100 \pm 0.005 \\
(1.00)\end{array}$ & $\begin{array}{c}18.104 \pm 3.228 \\
(1.00)\end{array}$ \\
\hline$+10 \mu \mathrm{M}$ TTM & $\begin{array}{c}0.483 \pm 0.088 \\
(1.31)\end{array}$ & $\begin{array}{c}6.939 \pm 0.853 \\
(2.39)\end{array}$ & $\begin{array}{c}0.071 \pm 0.018 \\
\quad(1.41)\end{array}$ & $\begin{array}{c}5.364 \pm 1.269 \\
(3.38)\end{array}$ \\
\hline$+30 \mu \mathrm{M} \mathrm{TTM}$ & $\begin{array}{c}0.221 \pm 0.024 \\
(2.86)\end{array}$ & $\begin{array}{l}2.286 \pm 0.205 \\
(7.26)^{* *}\end{array}$ & $\begin{array}{c}0.039 \pm 0.016 \\
(2.56)\end{array}$ & $\begin{array}{c}3.142 \pm 1.115 \\
\quad(5.76)\end{array}$ \\
\hline$+10 \mu \mathrm{M}$ Ver & $\begin{array}{c}0.346 \pm 0.045 \\
(1.83)\end{array}$ & $\begin{array}{l}1.901 \pm 0.350 \\
(8.73)^{* * * *}\end{array}$ & $\begin{array}{c}0.028 \pm 0.009 \\
\quad(3.527)\end{array}$ & $\begin{array}{c}0.414 \pm 0.012 \\
\quad(43.73)^{* * *}\end{array}$ \\
\hline Daunorubicin & $\begin{array}{c}0.114 \pm 0.005 \\
\quad(1.00)\end{array}$ & $\begin{array}{c}3.335 \pm 0.646 \\
(1.00)\end{array}$ & $\begin{array}{c}0.048 \pm 0.005 \\
(1.00)\end{array}$ & $\begin{array}{c}3.497 \pm 0.405 \\
(1.00)\end{array}$ \\
\hline$+10 \mu \mathrm{M}$ TTM & $\begin{array}{c}0.113 \pm 0.003 \\
(1.01)\end{array}$ & $\begin{array}{c}2.341 \pm 0.199 \\
(1.42)\end{array}$ & $\begin{array}{c}0.045 \pm 0.005 \\
(1.07)\end{array}$ & $\begin{array}{c}1.149 \pm 0.239 \\
(3.04)\end{array}$ \\
\hline$+30 \mu \mathrm{M}$ TTM & $\begin{array}{c}0.109 \pm 0.003 \\
(1.05)\end{array}$ & $\begin{array}{c}1.187 \pm 0.105 \\
(2.81)\end{array}$ & $\begin{array}{c}0.040 \pm 0.006 \\
(1.20)\end{array}$ & $\begin{array}{l}0.107 \pm 0.012 \\
\quad(32.68)^{* * *}\end{array}$ \\
\hline$+10 \mu \mathrm{M}$ Ver & $\begin{array}{c}0.110 \pm 0.004 \\
\quad(1.04)\end{array}$ & $\begin{array}{l}0.423 \pm 0.083 \\
\quad(7.88)^{* *}\end{array}$ & $\begin{array}{c}0.037 \pm 0.004 \\
\quad(1.28)\end{array}$ & $\begin{array}{l}0.009 \pm 0.001 \\
(388.56)^{* * * *}\end{array}$ \\
\hline Epirubicin & $\begin{array}{c}0.217 \pm 0.037 \\
(1.00)\end{array}$ & $\begin{array}{c}6.498 \pm 1.606 \\
(1.00)\end{array}$ & $\begin{array}{c}0.034 \pm 0.013 \\
(1.00)\end{array}$ & $\begin{array}{c}90.598 \pm 12.804 \\
(1.00)\end{array}$ \\
\hline$+10 \mu \mathrm{M}$ TTM & $\begin{array}{c}0.193 \pm 0.035 \\
\quad(1.12)\end{array}$ & $\begin{array}{c}3.667 \pm 0.198 \\
(1.77)\end{array}$ & $\begin{array}{c}0.022 \pm 0.018 \\
(1.54)\end{array}$ & $\begin{array}{c}7.566 \pm 1.040 \\
(11.97)^{* * *}\end{array}$ \\
\hline$+30 \mu \mathrm{M} \mathrm{TTM}$ & $\begin{array}{c}0.132 \pm 0.029 \\
(1.64)\end{array}$ & $\begin{array}{c}1.766 \pm 0.236 \\
(3.68)\end{array}$ & $\begin{array}{c}0.011 \pm 0.025 \\
\quad(3.09)\end{array}$ & $\begin{array}{c}1.919 \pm 0.077 \\
(47.21)^{* * *}\end{array}$ \\
\hline$+10 \mu \mathrm{M}$ Ver & $\begin{array}{c}0.125 \pm 0.007 \\
(1.74)\end{array}$ & $\begin{array}{l}0.461 \pm 0.042 \\
\quad(14.10)^{* * *}\end{array}$ & $\begin{array}{l}0.003 \pm 0.001 \\
\quad(11.33)^{* * *}\end{array}$ & $\begin{array}{l}0.286 \pm 0.028 \\
(316.78)^{* * *}\end{array}$ \\
\hline Docetaxel & $\begin{array}{c}0.206 \pm 0.044 \\
(1.00)\end{array}$ & $\begin{array}{c}22.546 \pm 1.581 \\
(1.00)\end{array}$ & $\begin{array}{c}0.010 \pm 0.001 \\
\quad(1.00)\end{array}$ & $\begin{array}{c}75.711 \pm 9.275 \\
(1.00)\end{array}$ \\
\hline$+10 \mu \mathrm{M}$ TTM & $\begin{array}{c}0.198 \pm 0.038 \\
(1.04)\end{array}$ & $\begin{array}{c}5.956 \pm 1.692 \\
(3.79)^{*}\end{array}$ & $\begin{array}{c}0.007 \pm 0.001 \\
\quad(1.43)\end{array}$ & $\begin{array}{c}1.969 \pm 0.010 \\
(38.45)^{* * *}\end{array}$ \\
\hline$+30 \mu \mathrm{M} \mathrm{TTM}$ & $\begin{array}{c}0.163 \pm 0.048 \\
(1.26)\end{array}$ & $\begin{array}{c}1.250 \pm 0.497 \\
(18.04)^{* * *}\end{array}$ & $\begin{array}{c}0.005 \pm 0.001 \\
(1.40)\end{array}$ & $\begin{array}{c}1.163 \pm 0.030 \\
(65.10)^{* * *}\end{array}$ \\
\hline$+10 \mu \mathrm{M}$ Ver & $\begin{array}{c}0.146 \pm 0.012 \\
(1.41)\end{array}$ & $\begin{array}{c}2.403 \pm 0.980 \\
\quad(9.38)^{* *}\end{array}$ & $\begin{array}{c}0.005 \pm 0.001 \\
(1.40)\end{array}$ & $\begin{array}{c}0.087 \pm 0.031 \\
(870.24)^{* * *}\end{array}$ \\
\hline Cisplatin & $\begin{array}{c}6.763 \pm 0.56 \\
(1.00)\end{array}$ & $\begin{array}{c}3.605 \pm 0.494 \\
(1.00)\end{array}$ & $\begin{array}{c}28.478 \pm 4.580 \\
(1.00)\end{array}$ & $\begin{array}{c}32.956 \pm 1.455 \\
(1.00)\end{array}$ \\
\hline$+10 \mu \mathrm{M}$ ТTM & $\begin{array}{c}5.806 \pm 0.59 \\
(1.16)\end{array}$ & $\begin{array}{c}3.521 \pm 0.361 \\
(1.02)\end{array}$ & $\begin{array}{c}23.122 \pm 2.812 \\
(1.23)\end{array}$ & $\begin{array}{c}29.732 \pm 3.591 \\
(1.11)\end{array}$ \\
\hline$+30 \mu \mathrm{M}$ TTM & $\begin{array}{c}5.474 \pm 0.57 \\
(1.24)\end{array}$ & $\begin{array}{c}3.281 \pm 0.389 \\
(1.10)\end{array}$ & $\begin{array}{c}19.492 \pm 3.181 \\
(1.46)\end{array}$ & $\begin{array}{c}24.488 \pm 4.600 \\
(1.35)\end{array}$ \\
\hline$+10 \mu \mathrm{M}$ Ver & $\begin{array}{c}5.379 \pm 0.74 \\
(1.25)\end{array}$ & $\begin{array}{c}3.222 \pm 0.346 \\
(1.12)\end{array}$ & $\begin{array}{c}15.217 \pm 1.175 \\
(1.87)\end{array}$ & $\begin{array}{c}20.964 \pm 3.308 \\
(1.572)\end{array}$ \\
\hline
\end{tabular}

Cells were treated with a various concentrations of conventional chemotherapeutic drugs in combination with or without TTM and analyzed by MTT and CCK-8 assays.

a Data are presented as mean $\pm \operatorname{SEM}(n=3)$ of at least three independent experiments.

${ }^{\mathrm{b}}$ Reversal fold change $(\mathrm{RF})=\mathrm{IC}_{50}\left(\mathrm{MDR}\right.$ cells) $/ \mathrm{IC}_{50}$ (MDR cells treated with TTM or Ver treatment). ${ }^{*}$ denotes $P<0.05,{ }^{* *}$ denotes $P<0.01$ and ${ }^{* * *}$ denotes $P<0.001$ compared to control or untreated group $\mathrm{IC}_{50}$. 
A<smiles>CC(C)C[C@H]1C[C@@]2(CC[C@@]3(C(C)C)C[C@H]32)OC2=C1C(=O)C(C)(C)C(=O)C2(C)C</smiles>

Tomentodione M Molecular Formula: $\mathrm{C}_{25} \mathrm{H}_{39} \mathrm{O}_{3}$ Molecular Weight: 387.28

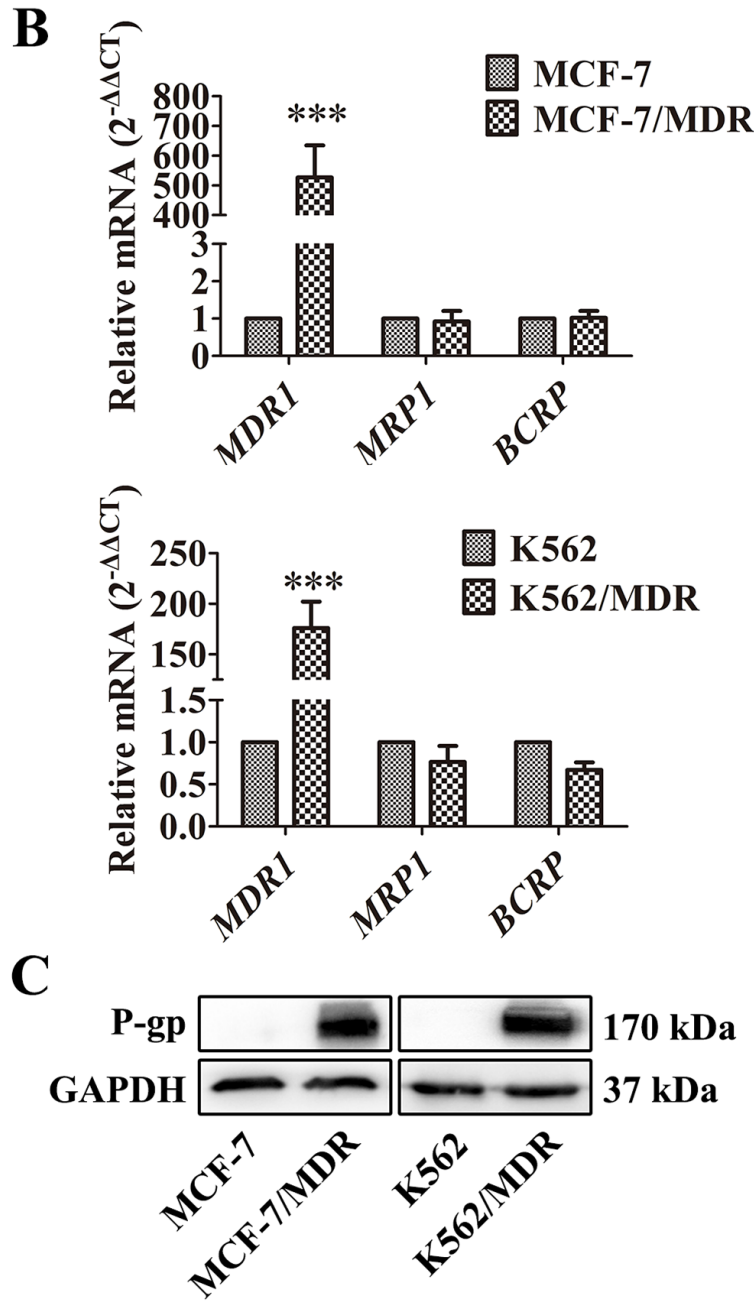

D
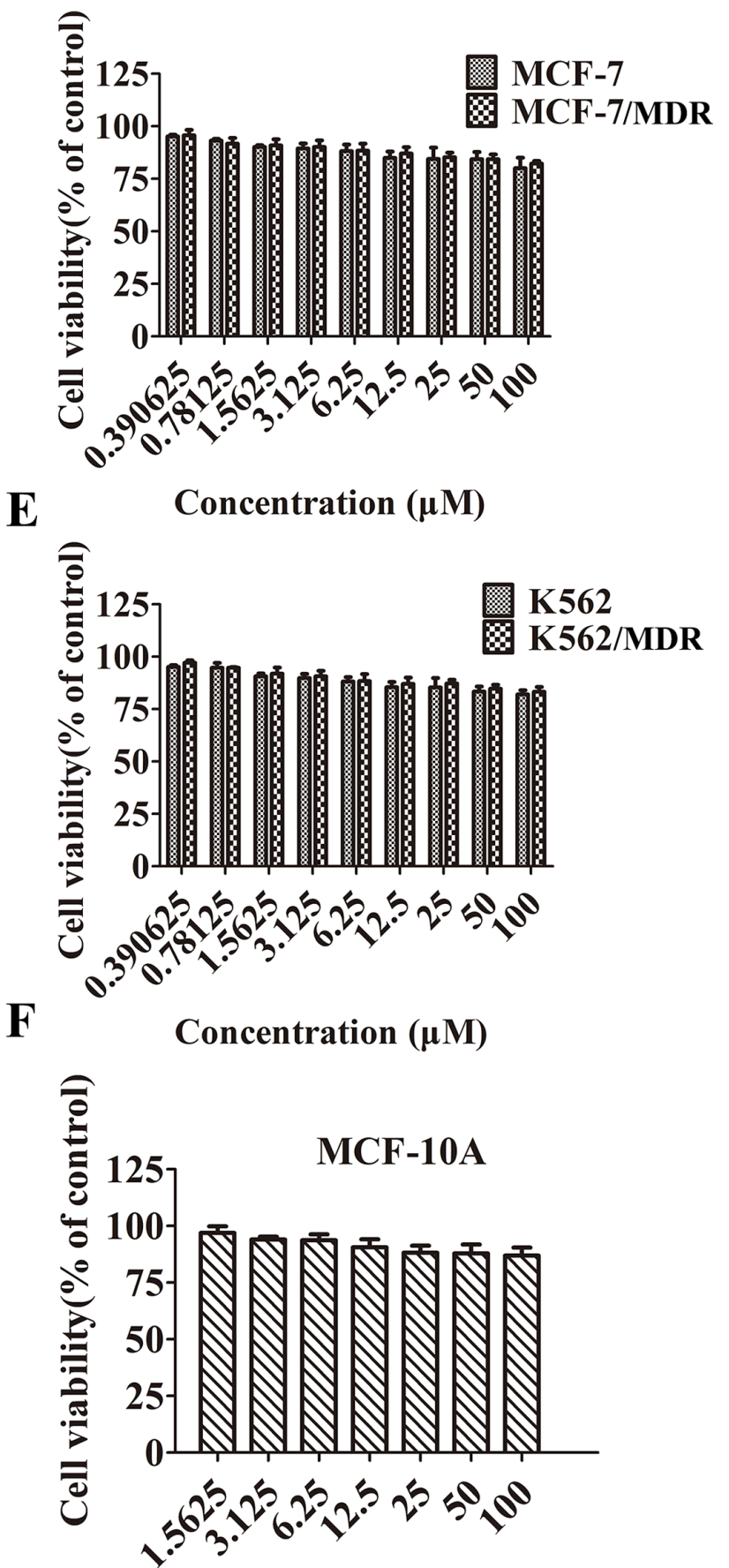

Concentration $(\mu \mathrm{M})$

Figure 1: Effect of TTM on cancer cell toxicity and expression of ABC transporters. (A) Chemical structure and molecular weight of Tomentodione M (TTM). (B) QRT-PCR analysis of MDR1, MRP1 and BCRP mRNA levels relative to GAPDH in parental and multi-drug resistant (MDR) MCF-7 and K562 cancer cells. Note: The relative mRNA levels are expressed as fold-changes relative to control group, which is arbitrarily represented as 1 . The data are representative of at least 6 replicates. (C) Representative western blot showing P-gp protein levels in MCF-7/MDR and K562/MDR cells relative to their corresponding parental cells. GAPDH was used as loading control. (D-F) MTT and CCK-8 assays showing cell viability of multidrug resistant cell lines (MCF-7/MDR and K562/MDR) and their corresponding parental cell lines (MCF-7 and K562), as well as non-tumor cell line (MCF-10A) treated with 0-100 $\mu \mathrm{M}$ TTM for 48 hr. Inhibition of cell proliferation by different concentrations of TTM were calculated based on the ratio of absorbance in treatment and control samples. The absorbance was evaluated at a test wavelength of $570 \mathrm{~nm}$, and a reference wavelength of $630 \mathrm{~nm}$ in MTT assays. The absorbance at $450 \mathrm{~nm}$ was used in CCK-8 assays. Note: Values represent mean \pm SEM from three independent experiments. ${ }^{* * *}$ denotes $P$ $<0.001$ compared to control. 


\section{TTM increases apoptosis in Doc-treated MDR cancer cells}

We evaluated the effects of TTM on Doc-induced apoptosis. As shown in Figure 2A-2B, MDR cells treated with (+) or without (-) $30 \mu \mathrm{M}$ TTM or $10 \mu \mathrm{M}$ Ver combined with $1 \mu \mathrm{M}$ Doc for $48 \mathrm{hr}$. The results indicated that treatment of the MDR cells with $1 \mu \mathrm{M}$ Doc, especially with $30 \mu \mathrm{M}$ TTM or $10 \mu \mathrm{M}$ Ver alone, did not cause notable apoptosis, while combination treatment dramatically increased Doc-induced apoptosis $(30.4 \% \pm 3.68 \%$ and $37.6 \% \pm 1.97 \%$ for Ver and TTM combined with Doc respectively, versus $12.65 \% \pm 3.74 \%$ for Doc alone in MCF-7/MDR cells; $27.65 \% \pm 2.33 \%$ and $30.15 \% \pm 2.62 \%$ for Ver and TTM combined with Doc respectively, versus $7.8 \% \pm 1.84 \%$ for Doc alone in K562/MDR cells). In the parental MCF-7 and K562 cells, Doc treatment alone induced significant cell death (Supplementary Figures 1 and 2). Moreover, TTM increased Doc-induced apoptosis in K562 parental cells, but had no effect on MCF-7 cells.

Caspases are important mediators of cellular apoptosis that cleave various proteins that are necessary for cell survival and function [40]. We assessed the status of cleaved caspases 3 and 9 as well as PARP in MDR cells treated with TTM and Doc in combination. As shown in Figure 2C, MCF-7/MDR and K562/MDR cells treated with a combination of Doc and TTM showed increased cleaved caspases-3, -9 and PARP levels. This suggested that TTM treatment enhances Doc-induced apoptosis in MDR cells by activating the apoptotic machinery.

\section{TTM decreases clonogenicity of Doc or DOX- treated MDR cancer cells}

MDR cancer cells with high P-gp expression are highly malignant and resistant to traditional chemotherapeutic agents $[41,42]$. Therefore, we tested the effects of TTM on clonogenicity of parental and MDR MCF-7 cells treated with $1 \mu \mathrm{M}$ Doc or DOX with or without $30 \mu \mathrm{M}$ TTM. MCF-7/MDR cells formed greater number of colonies than the parental MCF-7 cells (Figure 2D and Supplementary Figure 3). However, combined treatment of MCF-7/MDR cells with $1 \mu \mathrm{M}$ Doc or $1 \mu \mathrm{M}$ DOX in presence of $30 \mu \mathrm{M}$ TTM decreased the colonies by $53.2 \%$ and $68.1 \%$, respectively (Figure 2D Column 4 and Supplementary Figure 3 Column 4). However, parental MCF-7 cells treated with $1 \mu \mathrm{M}$ Doc or $1 \mu \mathrm{M}$ DOX or $1 \mu \mathrm{M}$ Doc $/ 1 \mu \mathrm{M}$ DOX with $30 \mu \mathrm{M}$ TTM showed no difference in colony numbers (Figure 2D Column 2 and Supplementary Figure 3 Column 2). These results demonstrated that TTM enhanced the cytotoxicity of Doc or DOX treated MDR cancer cells by decreasing their colony formation ability.

\section{TTM enhances the accumulation of DOX and Rh123 in MDR cells}

We next determined the effects of TTM on drug accumulation in MDR cancer cells by fluorescent detection of DOX and Rh123 dye in the presence and absence of TTM and Ver. Treatment with $10 \mu \mathrm{M}$ TTM and $10 \mu \mathrm{M}$ Ver increased intracellular levels of DOX by 3.71- and 1.71-fold in MCF-7/MDR cells, and 3.48- and 3.61-fold in K562/MDR cells, respectively (Figure 3A). The efflux of DOX was reduced by 1.32 and 1.54-fold in MCF-7/MDR cells, and 2.22 and 2.27-fold in K562/MDR cells upon treatment with $10 \mu \mathrm{M}$ TTM and $10 \mu \mathrm{M}$ Ver, respectively (Figure 3A). Moreover, treatment with $10 \mu \mathrm{M}$ TTM and 10 $\mu \mathrm{M}$ Ver increased DOX accumulation by $1.33-$ and 1.16fold in MCF-7 cells and 1.31- and 1.26-fold in K562 cells, respectively (Supplementary Figure 4). Treatment with 10 $\mu \mathrm{M}$ TTM and $10 \mu \mathrm{M}$ Ver reduced DOX efflux by 1.47 - and 2.30- fold in MCF-7 cells, and 1.26- and 1.17-fold in K562 cells, respectively (Supplementary Figure 4).

Since P-gp plays an important role in DOX efflux, we examined the effects of TTM by assessing the accumulation and efflux of Rh123, which is a specific P-gp substrate [43]. We found that treatment with $10 \mu \mathrm{M}$ Ver and 10,30 or 50 $\mu \mathrm{M}$ TTM increased Rh123 accumulation by 1.49-, 1.22- , 1.53- and 1.87-fold in MCF-7/MDR cells, 1.11-, 1.12-, 1.25- and 1.46-fold in MCF-7 cells, 1.28-, 1.20-, 1.31- and 1.39-fold in K562/MDR and 1.20-, 1.06-, 1.16- and 1.27fold in K562 cells, respectively (Figure 3B). Moreover, as shown in Figure $3 \mathrm{C}$, treatment with $10 \mu \mathrm{M}$ Ver and 10, 30 or $50 \mu \mathrm{M}$ TTM reduced Rh123 efflux by $2.84-, 2.15-, 3.42-$ and 4.26-fold in MCF-7/MDR, 1.50-, 1.36-,1.67- and 1.76-fold in MCF-7, 5.85-, 5.45-, 6.72- and 7.94-fold in K562/MDR, $1.07-1.14-, 1.19$ - and 1.20 -fold in K562 cells, respectively. Furthermore, laser confocal microscopy showed that TTM enhanced cytosolic accumulation of Rh123 in MCF-7/ MDR and K562/MDR cells than controls (Supplementary Figure 5). These results demonstrated that TTM increased intracellular concentrations of DOX by inhibiting P-gp efflux function in MDR cells.

\section{TTM decreases P-gp levels in MDR cells}

Next, we analyzed if TTM decreased P-gp expression in MDR cells. The P-gp protein levels decreased in a dose-dependent manner in MCF-7/ MDR and K562/MDR cells when treated with 0-30 $\mu \mathrm{M}$ TTM for $48 \mathrm{hr}$ (Figure 4A-4B). Moreover, P-gp levels decreased in a time-dependent manner when treated 30 $\mu \mathrm{M}$ TTM for $48 \mathrm{hr}$ (Figure 4C). We transfected MCF-7 cells with $\mathrm{P}$-gp overexpression plasmid to determine if TTM effects on MDR were related to P-gp protein levels. We observed that $30 \mu \mathrm{M}$ TTM decreased P-gp levels in MDR1-overexpressing MCF-7 cells (Figure 4D). We also 
A

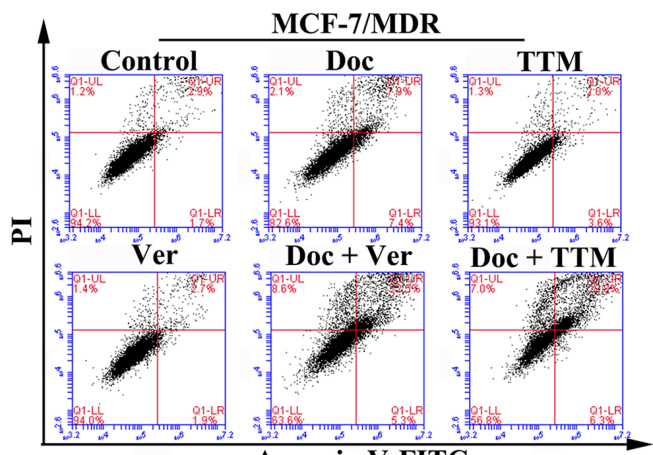

Annexin V-FITC

MCF-7/MDR

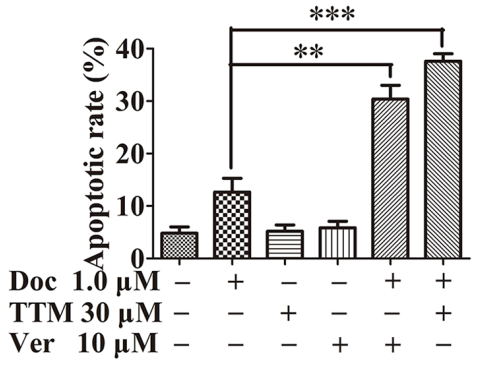

C

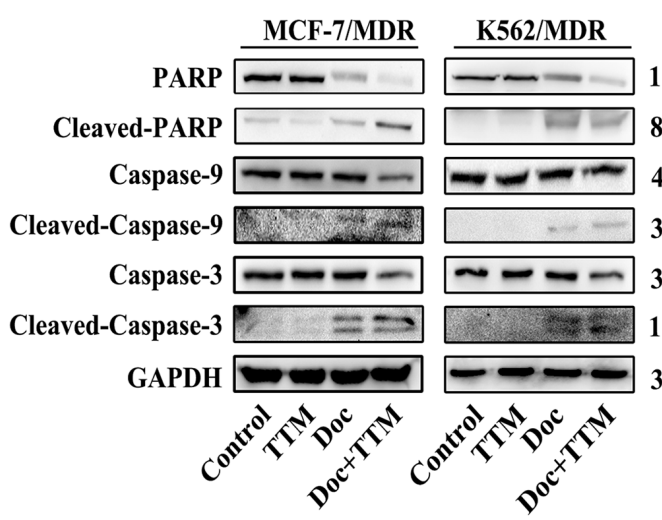

D

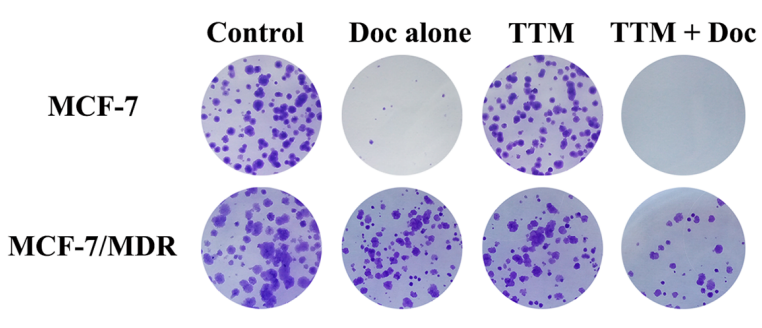

B

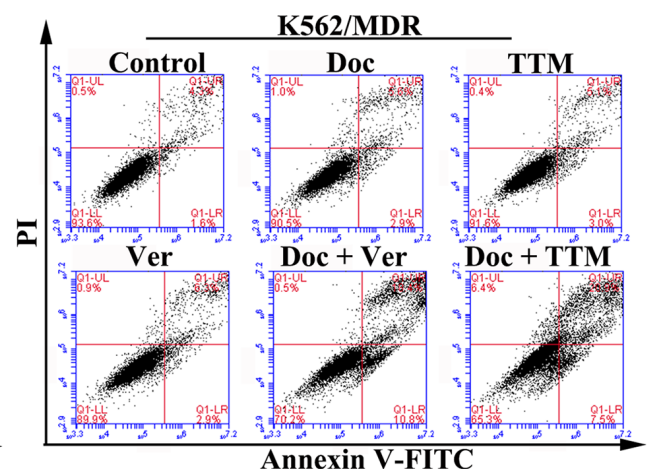

K562/MDR
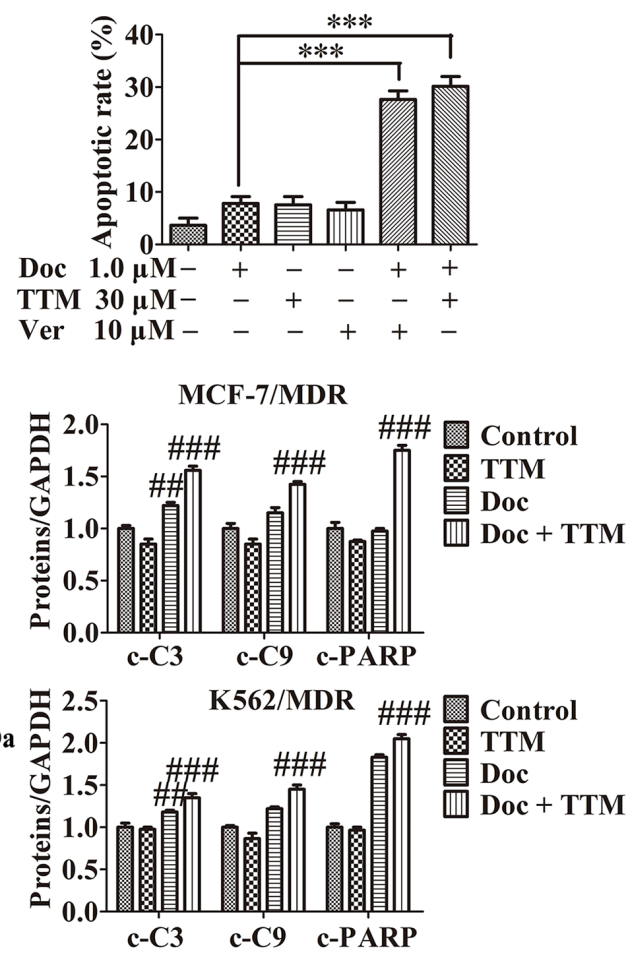

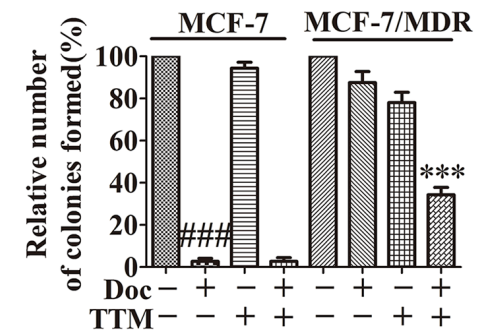

Figure 2: Effect of TTM on apoptosis and clonogenicity of Doc-treated MDR cancer cells. (A-B) Flow cytometry analysis of cellular apoptosis in (A) MCF-7/MDR and (B) K562/MDR cells treated with $1 \mu \mathrm{M}$ Doc, $30 \mu \mathrm{M}$ TTM, $10 \mu \mathrm{M}$ Ver, or combination of 1 $\mu \mathrm{M}$ Doc plus $10 \mu \mathrm{M}$ Ver plus $30 \mu \mathrm{M}$ TTM for $48 \mathrm{hr}$ as determined by AnnexinV-FITC/PI staining. Note: Data represent three independent experiments. As shown, MDR cells were resistant to Doc, and both TTM and Ver enhanced Doc-induced apoptosis. ${ }^{* *}$ denotes $P<0.01$ and ${ }^{* * *}$ denotes $P<0.001$ compared to Doc alone treatment. (C) Quantitative western blot analysis of procaspase-9, cleaved caspase-9, procaspase-3, cleaved caspase-3, PARP and cleaved PARP in MCF-7/MDR and K562/MDR cells incubated with $1 \mu \mathrm{M}$ Doc with or without $30 \mu \mathrm{M}$ TTM for $48 \mathrm{hr}$. Note: GAPDH was used as internal control. ${ }^{\#}$ denotes $P<0.01$ and ${ }^{\# \#}$ denotes $P<0.001$ compared to control. (D) Histogram plots showing total number of colonies in MCF-7 and MCF-7/MDR cells treated with $1 \mu$ M Doc with or without $30 \mu \mathrm{M}$ TTM for 48 hr. Note: Cells were plated in 6-well plates containing RPMI 1640 plus 10\% FBS at a density of 1000 cells per well. Colonies were counted after 15 days. The data are presented as the mean \pm SEM from three independent experiments. \#\#\# denotes $P<0.001$ compared to control. $^{* * *}$ denotes $P<0.001$ compared to Doc alone treatment. 
A
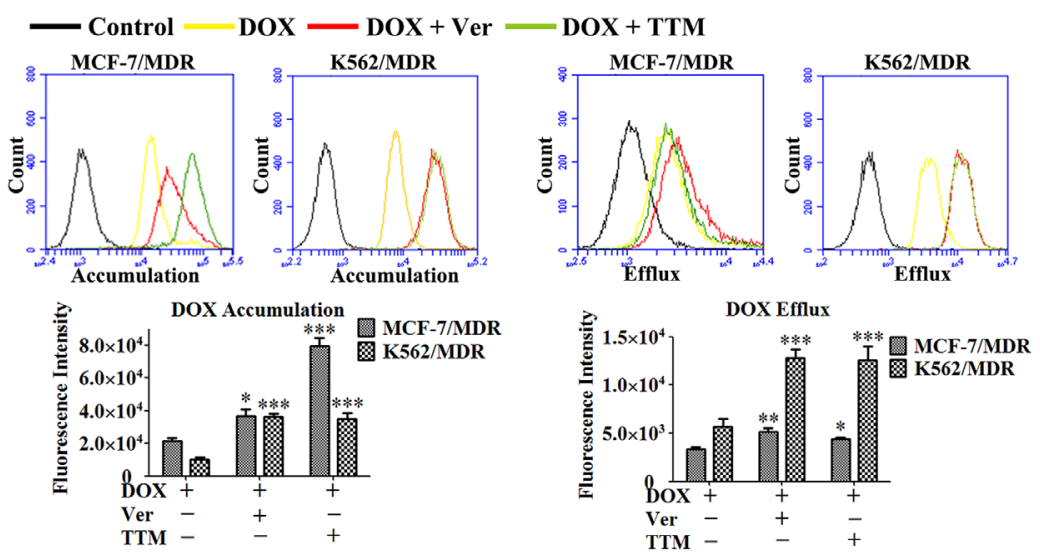

B
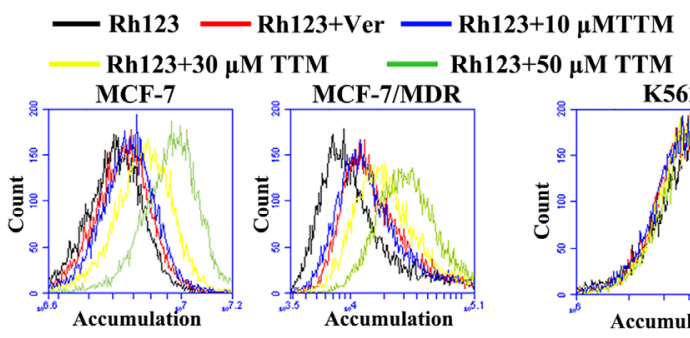
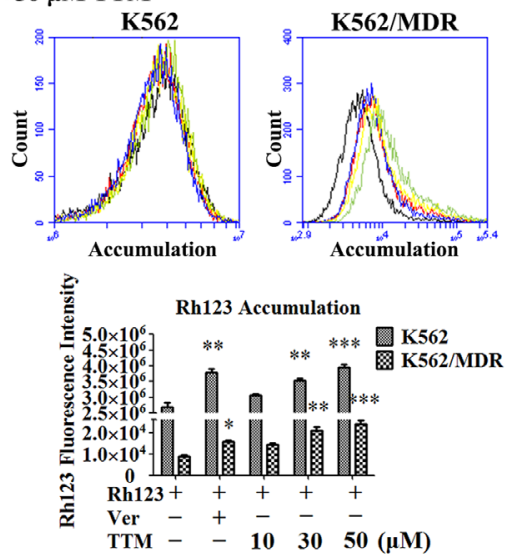

C
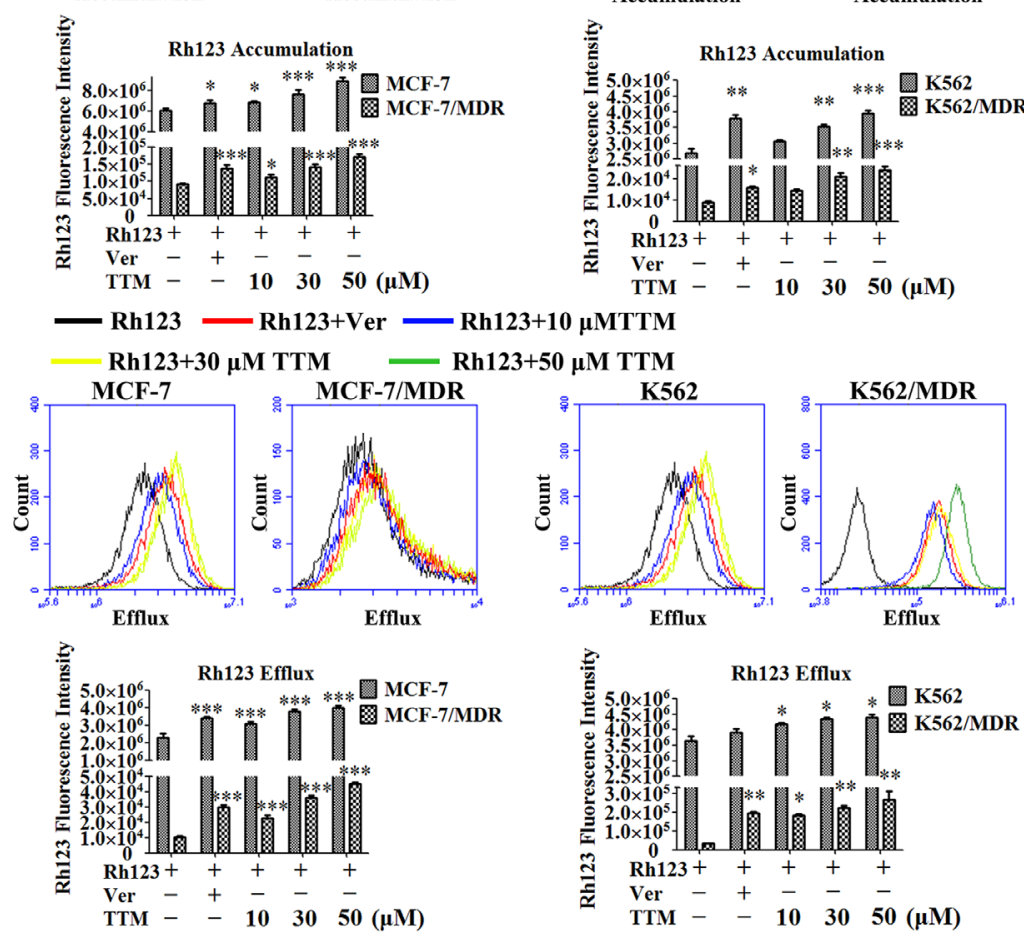

Figure 3: Effect of TTM on the accumulation and efflux of DOX and Rh123 in MDR cancer cells. (A) Histogram plots showing flow cytometry analysis of intracellular DOX accumulation in MCF-7/MDR and K562/MDR cells pre-incubated for $4 \mathrm{hr}$ with or without $10 \mu \mathrm{M}$ TTM or $10 \mu \mathrm{M}$ Ver (positive control) followed by incubation with $10 \mu \mathrm{M}$ DOX as determined by flow cytometry. Also shown are histogram plots for DOX retention assay, wherein MDR cells were pre-incubated for $3 \mathrm{hr}$ with $10 \mu \mathrm{M}$ DOX followed by incubation for $4 \mathrm{hr}$ in medium with or without $10 \mu \mathrm{M}$ TTM or $10 \mu \mathrm{M}$ Ver. Subsequently, intracellular DOX levels were determined by flow cytometry. (B) Histogram plots showing flow cytometry analysis of Rh123 dye accumulation in MDR and parental MCF-7 and K562 cells pretreated with or without $10,30,50 \mu \mathrm{M} \mathrm{TTM}$ or $10 \mu \mathrm{M}$ Ver for $1.5 \mathrm{hr}$ followed by incubation with $5 \mu \mathrm{M} \mathrm{Rh} 123$ in the dark for $1.5 \mathrm{hr}$. (C) Histogram plots showing flow cytometry analysis of Rh123 efflux in MDR and parental MCF-7 and K562 cells that were first incubated with $5 \mu \mathrm{M}$ Rh123 in the dark for $1.5 \mathrm{hr}$ followed by incubation with or without $10,30,50 \mu \mathrm{M}$ TTM or $10 \mu \mathrm{M}$ Ver for $1.5 \mathrm{hr}$. Intracellular fluorescence of Rh123 was detected by flow cytometry. Note: The data are represented as the mean \pm SEM from three independent experiments. " denotes $P<0.05,{ }^{* *}$ denotes $P<0.01$ and ${ }^{* * *}$ denotes $P<0.001$ compared to DOX or Rh123 alone treatments. 
A
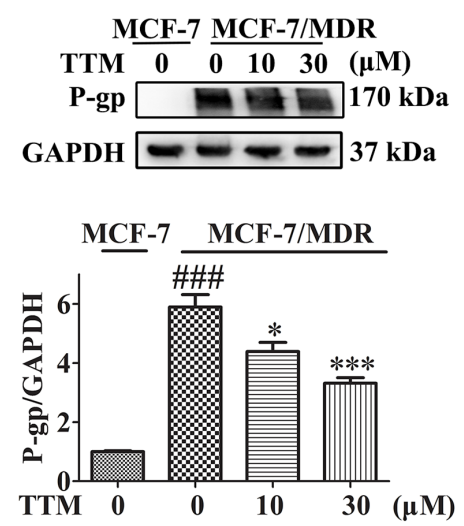

C
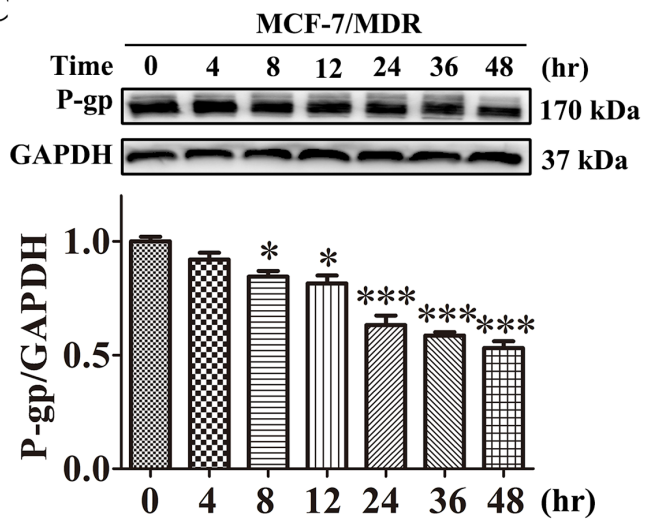

D
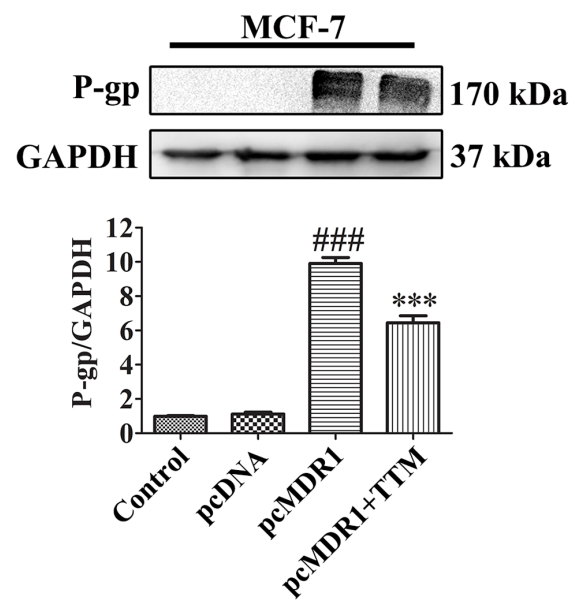

r)

$\mathbf{E}$
$\mathrm{B}$
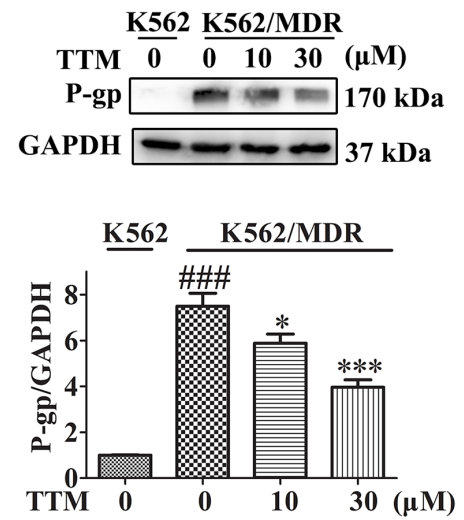
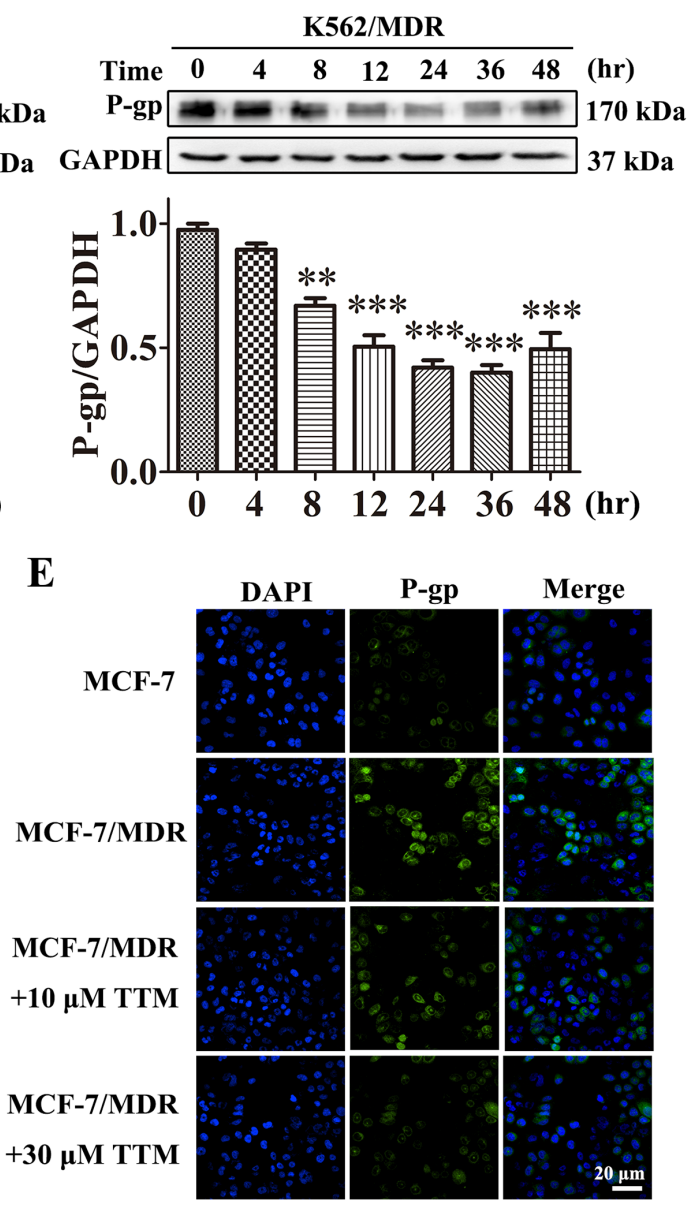

Figure 4: TTM decreases P-gp levels in MDR cancer cells. (A) Representative western blot showing P-gp expression in MCF7/MDR cells treated with 0 to $30 \mu \mathrm{M}$ TTM for $48 \mathrm{hr}$. MCF-7 cells were used as the negative control. ${ }^{\# \#}$ denotes $P<0.001$ compared to MCF-7. " denotes $P<0.05$ and ${ }^{* * *}$ denotes $P<0.001$ compared to MCF-7/MDR. (B) Representative western blot showing P-gp expression in K562/MDR cells treated with 0 to $30 \mu \mathrm{M}$ TTM for $48 \mathrm{hr}$. K562 cells were used as the negative control. ${ }^{\# \#}$ denotes $P<0.001$ compared to K562. " denotes $P<0.05$ and ${ }^{* * *}$ denotes $P<0.001$ compared to K562/MDR. (C) Representative western blot analysis of P-gp levels in MCF-7/MDR and K562/MDR cells treated with $30 \mu \mathrm{M}$ TTM at 0, 4, 8, 12, 24, 36 and $48 \mathrm{hr} .{ }^{*}$ denotes $P<0.05,{ }^{* *}$ denotes $P<0.01$ and ${ }^{* * *}$ denotes $P<0.001$ are all in comparison to control. (D) Representative western blot analysis of P-gp protein levels in MCF-7 cells transfected with control or P-gp overexpression plasmid for $24 \mathrm{hr}$ followed by treatment with or without $30 \mu \mathrm{M}$ TTM for $48 \mathrm{hr}$. Note: \#\#\# denotes $P<0.001$ versus pcDNA and ${ }^{* * *}$ denotes $P<0.001$ versus pcMDR1. (E) Representative confocal microscopy images showing subcellular localization of the P-gp protein in MCF-7/MDR and MCF-7 cells treated with or without 10 or $30 \mu \mathrm{M}$ TTM for $48 \mathrm{hr}$. The P-gp immunostaining is shown in green and the DAPI stained nuclei are shown in blue. Scale bar equals $20 \mu \mathrm{M}$. Quantitative data are presented as the mean \pm SEM from three independent experiments. 
showed by laser scanning confocal microscopy that P-gp levels were higher in MCF-7/MDR cells than MCF-7 cells; TTM reduced P-gp levels in MCF-7/MDR cells in a concentration dependent manner (Figure 4E). These data demonstrated that TTM decreased MDR by lowering P-gp expression.

\section{TTM inhibits p38 MAPK signaling}

P-gp expression is regulated by MAPK signaling pathway and therefore inhibition of MAPK signaling is an effective therapeutic approach to overcome MDR [44]. Therefore, we analyzed the phosphorylation levels of JNK, ERK and p38 MAPKs in TTM-treated MDR cells. First, we observed increased phospho-p38 and phosphoJNK levels in MCF-7/MDR and K562/MDR cells than the parental MCF-7 and K562 cells (Figure 5A). Moreover, TTM treatment decreased phospho-p38 and phospho-JNK levels, whereas phospho-ERK levels remained unchanged in MDR cells (Figure 5A).

Next, we used the MTT assay to determine the effects of JNK inhibitor SP600125 and p38 MAPK inhibitor SB203580 on Doc-treated MCF-7/MDR cells. We observed that p38 MAPK inhibitor, SB203580 decreased $\mathrm{IC}_{50}$ for Doc in MCF-7/MDR cells, whereas JNK inhibitor, SP600125 had no effect (SB203580: 0.83 $\pm 0.09 \mu \mathrm{M}$; SP600125: $23.76 \pm 3.43 \mu \mathrm{M}$; no treatment: $21.88 \pm 2.00 \mu \mathrm{M}$; Figure 5B). We further observed that TTM treatment did not further decrease $\mathrm{IC}_{50}$ of Doc in presence of SB203580 (SB203580 plus TTM: $0.81 \pm 0.09$ $\mu \mathrm{M}$; Figure 5B). In K562/MDR cells, similar results were obtained for Doc cytotoxicity (SB203580: $0.9 \pm 0.1 \mu \mathrm{M}$; SP600125: $77.97 \pm 7.62 \mu \mathrm{M}$; Doc only: $77.23 \pm 9.82 \mu \mathrm{M}$; SB203580 plus TTM: $0.85 \pm 0.10 \mu \mathrm{M}$; Figure $5 \mathrm{~B})$. This suggested that TTM decreased P-gp levels by inhibiting p38 MAPK. SB203580 decreased Doc resistance of MDR cells more effectively than TTM and did not inhibit cell proliferation at the concentrations used in our assays (Supplementary Figure 6).

Next, we tested the effects of $10 \mu \mathrm{M}$ SB203580 in MDR cells. SB203580 reduced phospho-p38 MAPK levels in both MCF-7/MDR and K562/MDR cells (Figure 5C). We observed 1.38- and 1.67-fold reduced P-gp expression in SB203580 treated MCF-7/MDR and K562/ MDR cells than the corresponding untreated cells (Figure 5C). This demonstrated that the p38 MAPK pathway regulated P-gp expression.

We then investigated if SB203580 treatment enhanced apoptosis in Doc treated MCF-7/MDR and K562/MDR cells by FACS analysis of AnnexinV-FITC/ PI staining. SB203580 treatment alone did not induce apoptosis, but, it reduced phospho-p38 levels in MDR cells (Figure 5D and Figure 5C). We observed slight karyopyknosis by laser confocal microscopy in MCF-7 and MCF-7/MDR cells treated with $10 \mu \mathrm{M}$ SB203580 alone (data not shown). However, when MDR cells were pretreated with $10 \mu \mathrm{M}$ SB203580 for $1 \mathrm{~h}$, they demonstrated increased apoptosis when treated with Doc than Doc alone $(40.77 \% \pm 2.87 \%$ for SB2 03580 combined with Doc, versus $14.4 \% \pm 1.25 \%$ for Doc alone in MCF-7/ MDR cells; $32.6 \% \pm 1.75 \%$ for SB203580 combined with Doc, versus $8.33 \% \pm 0.88 \%$ for Doc alone in K562/MDR cells) (Figure 5D). TTM did not further enhance apoptosis induced by SB203580 in Doc-treated MDR cells (Figure 5D). These results indicated that inhibition of p38 MAPK enhanced chemosensitivity of MDR cells by activating apoptosis.

\section{TTM inhibits p38 MAPK-induced P-gp in MCF-7 and K562 cells}

Finally, we verified if TTM decreased P-gp expression in MDR cells by inhibiting p38 MAPK signaling pathway. First, we transfected MCF-7 and K562 parental cells with p38 overexpression vector (pMT3 p38) for $24 \mathrm{hr}$. Then, we treated the cells with or without TTM for an additional $48 \mathrm{hr}$ and examined the levels of P-gp, p38 and phospho-p38. Western blot analysis demonstrated that total and phosphorylated p38 MAPK as well as P-gp levels were higher in p38 MAPK-overexpressing MCF-7 and K562 cells that were not treated with TTM (Figure 6A). However, TTM-treated p38 MAPK-overexpressing MCF-7 and K562 cells showed decreased levels of phospho-p38 and P-gp (Figure 6A). Moreover, qRT-PCR data demonstrated that TTM inhibited MDR1 mRNA levels in p38 MAPK-overexpressing MCF-7 and K562 cells (Supplementary Figure 7). We also observed that p38 MAPK-overexpressing MCF-7 and K562 cells treated with TTM showed increased DOX and Rh123 accumulation (Figure 6B). These results confirmed that TTM decreased P-gp levels by inhibiting p38 MAPK signaling.

\section{DISCUSSION}

In this study, we investigated the mechanism of action by which TTM, a novel meroterpenoid that is isolated from the leaves of Rhodomyrtus tomentosa reverses P-gp-mediated MDR in cancer cells. This is the first report of a syncarpic acid-conjugated terpenoid as a MDR modulator.

We demonstrated that TTM decreased the high expression of P-gp in MCF-7/MDR and K562/MDR cells, thereby reversing multidrug resistance within acceptable levels of cytotoxicity [27]. We demonstrated that TTM below $100 \mu \mathrm{M}$ did not inhibit cell proliferation in tumor and non-tumor cells (Figure 1D-1F), but, enhanced cytotoxicity of different chemotherapeutic drugs, DOX, DNR, EPI and Doc in the P-gp overexpressing cancer cell lines.

The $\mathrm{ABC}$ transporter proteins that mediate MDR are involved in cellular detoxification [20]. They pump out 
A
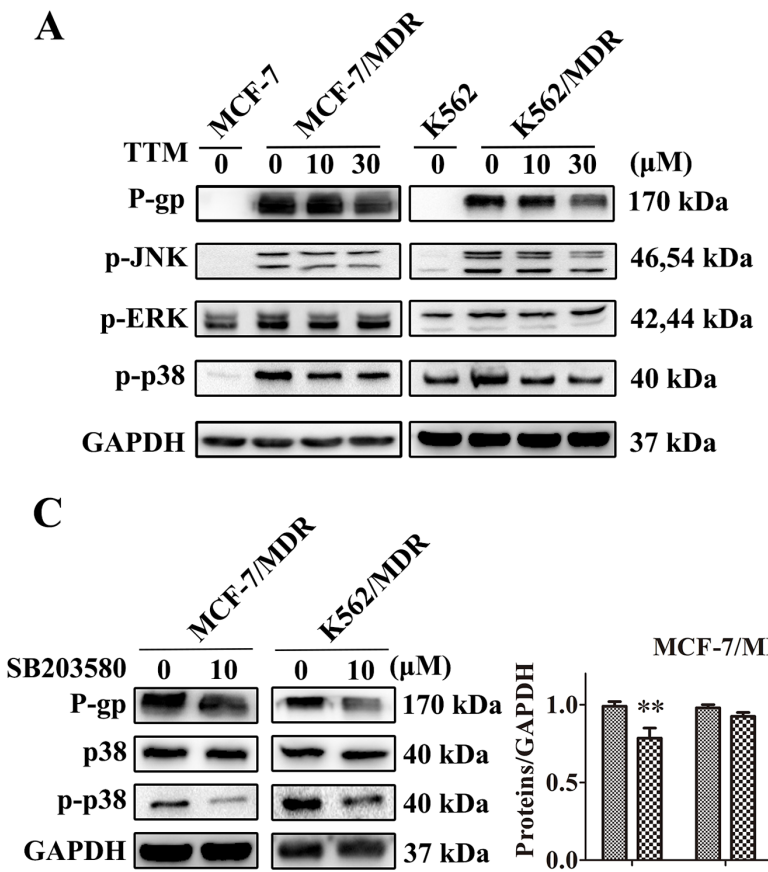

B

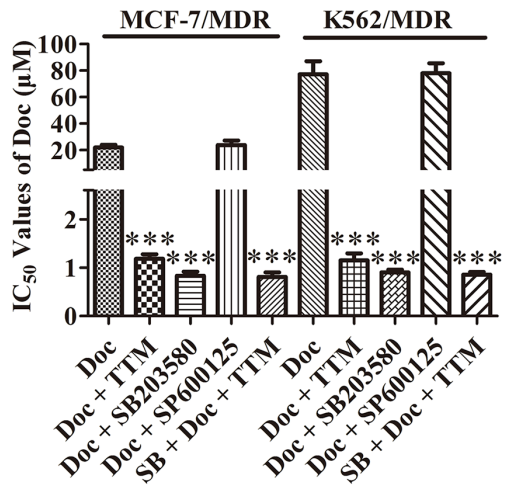

D

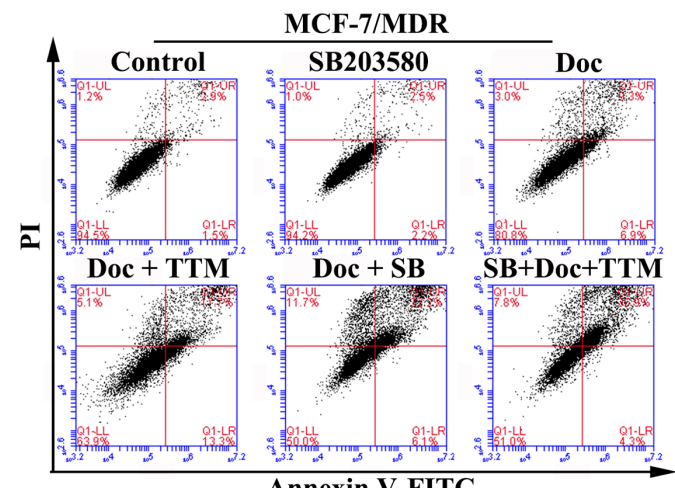

Annexin V-FITC

MCF-7/MDR

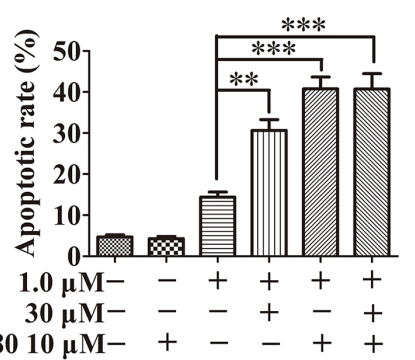

MCF-7/MDR K562/MDR
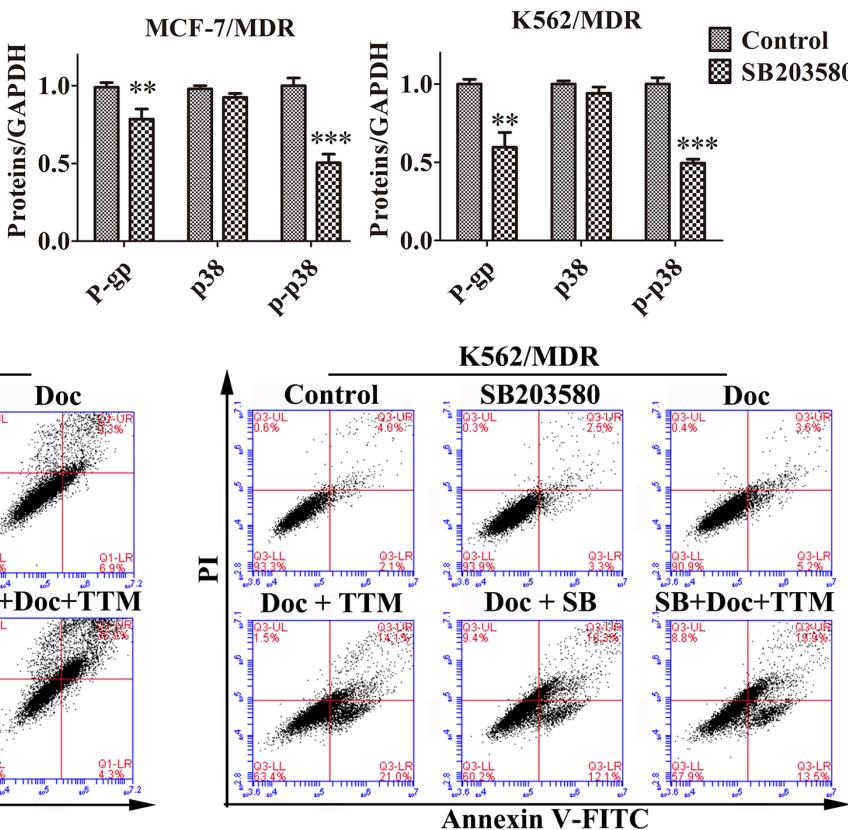

K562/MDR

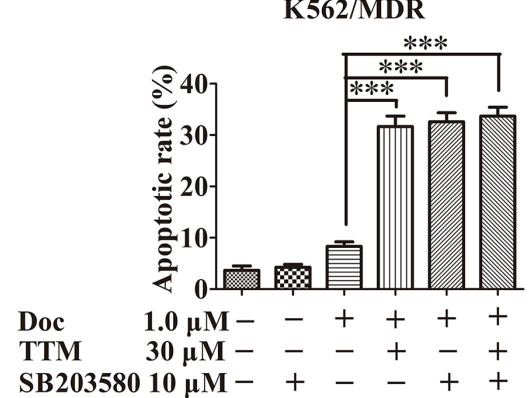

Figure 5: TTM reduces P-gp expression by suppressing p38 MAPK activation in MDR cancer cells. (A) Representative western blot analysis of P-gp and total and phosphorylated ERK, JNK and p38 MAPK proteins in MDR and parental MCF-7 and K562 cells treated with 10 or $30 \mu \mathrm{M}$ TTM for $48 \mathrm{hr}$. GAPDH was used as a loading control. (B) MTT assay results showing cell viability of MCF-7/ MDR or K562/MDR cells treated with the different concentrations of Doc in the absence or presence of $10 \mu \mathrm{M} \mathrm{SB} 203580,10 \mu \mathrm{M}$ SP600125 and/or $30 \mu \mathrm{M}$ TTM for $48 \mathrm{hr} .{ }^{* * *}$ denotes $P<0.001$ compared to Doc alone treated controls. (C) Representative western blot analysis of P-gp, p38 MAPK and phospho-p38 MAPK expression in MCF-7/MDR and K562/MDR cells treated with $10 \mu \mathrm{M} \mathrm{SB203580} \mathrm{for} 48$ hr. ${ }^{* *}$ denotes $P<0.01$ and ${ }^{* * *}$ denotes $P<0.001$ compared to control. (D) Flow cytometry analysis of cell death by AnnexinV-FITC/PI staining of MCF-7/MDR and K562/MDR cells incubated with $1 \mu \mathrm{M}$ Doc and/or $30 \mu \mathrm{M}$ TTM and/or $10 \mu \mathrm{M} \mathrm{SB} 203580$. The data are represented as percentage of apoptotic cells (Annexin $\mathrm{V}^{+} \mathrm{PI}^{+}$and AnnexinV $\mathrm{V}^{+} \mathrm{PI}$ ). Note: ${ }^{* *}$ denotes $P<0.01$ and ${ }^{* * *}$ denotes $P<0.001$ compared to the Doc alone treated cells. All experiments were repeated three times and data are represented in the histogram as mean $\pm \mathrm{SEM}$. 
cytotoxic drugs from cancer cells, thereby decreasing their intracellular levels and thus enhance tumor cell survival. Therefore, P-gp antagonists re-sensitize MDR cells to anticancer drugs [45]. We demonstrated that TTM increased docetaxel cytotoxicity in MDR cancer cells by enhancing apoptosis as shown by high cleaved-caspase-9/3 and cleaved-PARP levels (Figure 2A-2C). TTM treatment alone did not affect cell viability.

Increased clonogenicity is characteristic of malignant and drug-resistant cancer cells, which are responsible for cancer recurrence [46]. We demonstrated that MDR cells were more clonogenic and resistant to anticancer drugs, Doc or DOX. However, TTM in combination with Doc or DOX significantly reduced clonogenicity of MDR cancer cells (Figure 2D and Supplementary Figure 3). We further demonstrated that TTM enhanced intracellular accumulation of DOX and Rh123 in MDR cells by reducing their efflux in a concentration-dependent manner (Figure 3, Supplementary Figure 4 and Supplementary Figure 5).

Natural products inhibit MDR by either preventing efflux activity of P-gp or downregulating P-gp/MDR1 expression [47]. We observed that TTM significantly reduced P-gp expression in MCF-7/MDR and K562/MDR
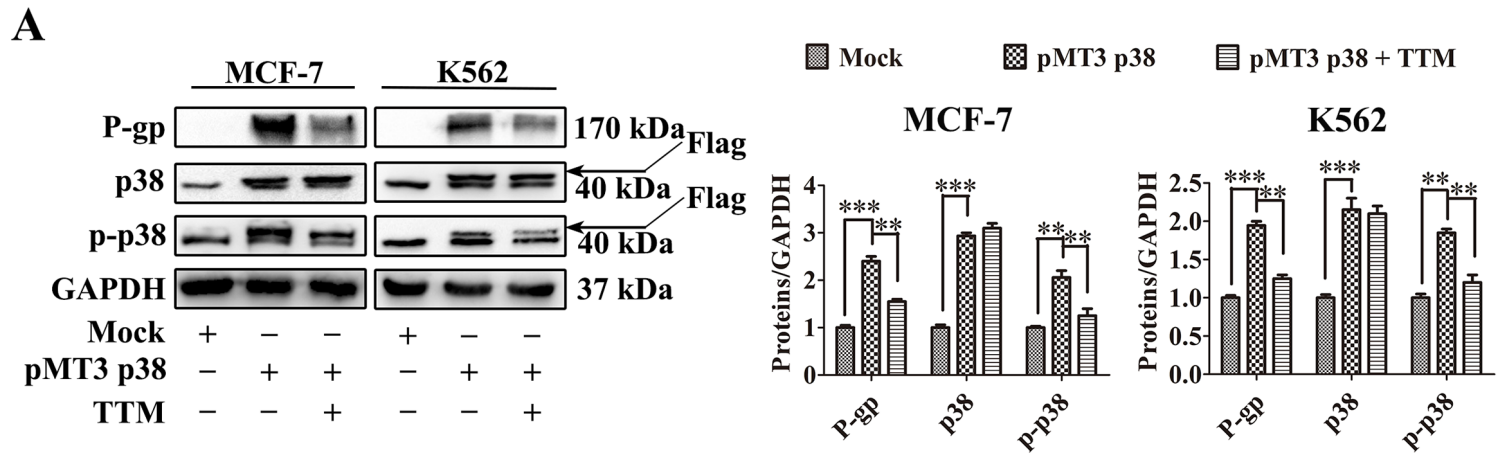

B
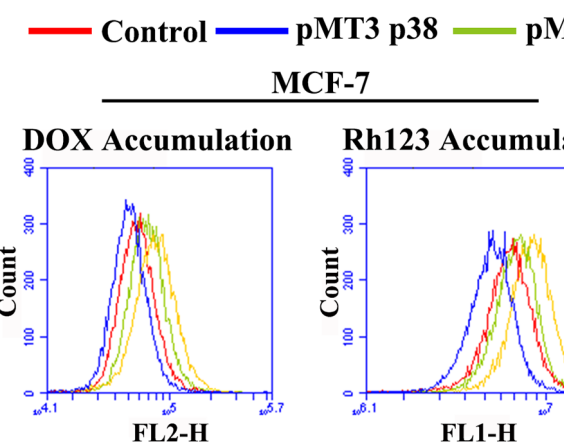

MCF-7
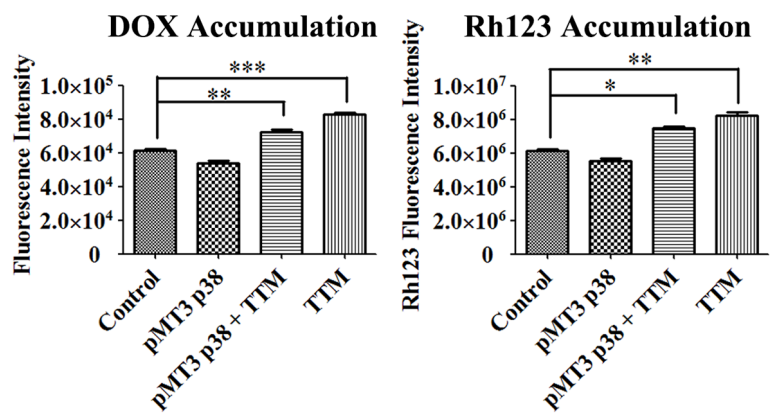

Rh123 Accumulation

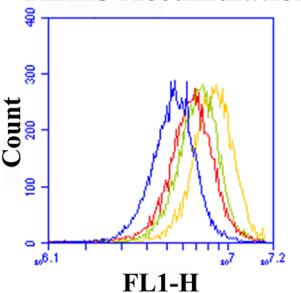

FL1-H
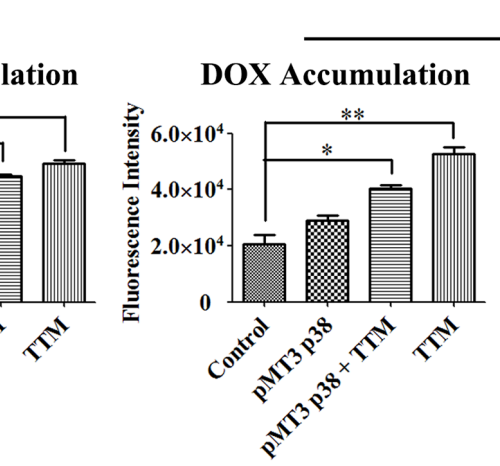

K562
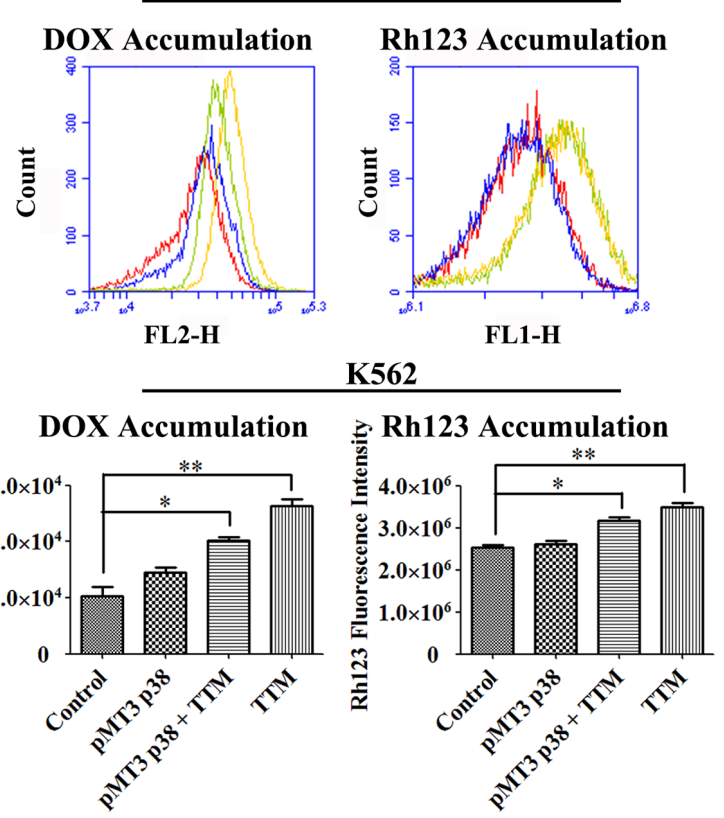

Figure 6: Effect of TTM on p38 MAPK-mediated increase in P-gp expression in parental MCF-7 and K562 cells. (A) Representative western blot analysis of P-gp and total and phosphorylated p38 MAPK levels in control and p38 MAPK overexpressing MCF-7 and K562 cells treated with or without $30 \mu \mathrm{M}$ TTM for $48 \mathrm{hr}$. MCF-7 and K562 cells were transfected with (+) or without (-) 10 $\mu \mathrm{g} / 1 \mathrm{pMT3}$-p38MAPK plasmid for $24 \mathrm{hr}$ to increase p38 MAPK expression. GAPDH was used as a loading control. Note: ${ }^{* *}$ denotes $P<$ 0.01 and $^{* * *}$ denotes $P<0.001$ compared to the pMT3 p38 group. (B) Flow cytometry analysis of DOX and Rh123 accumulation in control and p38 MAPK overexpressing MCF-7 and K562 cells treated with or without $30 \mu \mathrm{M} \mathrm{TTM}$ for $48 \mathrm{hr}$. After $48 \mathrm{hr}$, the cells were incubated with $10 \mu \mathrm{M}$ DOX for $4 \mathrm{hr}$ or $5 \mu \mathrm{M}$ Rh123 for $2 \mathrm{hr}$. Intracellular fluorescence was analyzed by flow cytometry. The data are presented as the mean \pm SEM from three independent experiments. Note: ${ }^{*}$ denotes $P<0.05,{ }^{* *}$ denotes $P<0.01$ and ${ }^{* * *}$ denotes $P<0.001$ compared to the control group. 
cells. Since P-gp has a long half-life [23], we examined the time-course of TTM downregulation of P-gp in the two MDR cancer cells (Figure 4C). We also found that TTM blocked MDR1 mRNA levels in the two MDR cancer cells (data not shown). This is the first report demonstrating the ability of TTM, a natural syncarpic acid-conjugated monoterpene in reducing the levels of MDR transporter, P-gp. We observed that decreased P-gp levels were observed after $8 \mathrm{hr}$ of TTM treatment in MDR cells, although increased Rh123 accumulation was observed at $4 \mathrm{hr}$ post-TTM treatment. This suggests that TTM inhibits P-gp function.

Anticancer drugs activate or inhibit signaling pathways that are associated with drug resistance of tumor cells [48]. ABC transporter expression has been associated with MAPK signaling [49, 50]. The MAPK signaling pathway is an important player in MDR and a promising target for systemic therapy $[5,51]$. Moreover, the p38 signaling pathway is associated with cellular apoptosis in cancer cells $[39,52]$. We demonstrated that MDR cells showed high phospho-p38 levels that correlated with P-gp overexpression in MCF-7/MDR and K562/MDR cells than the corresponding parental cells (Figure 5A). We further demonstrated that TTM decreased phopho-p38 MAPK and P-gp levels in a concentration-dependent manner. Moreover, the p38 MAPK inhibitor, SB203580 decreased Doc resistance of the MDR cancer cells. TTM did not alter the cytotoxicity of Doc upon SB203580 pre-treatment of MDR cancer cells (Figure 5B and Supplementary Figure 6). Moreover, SB203580 pre-treatment decreased P-gp levels in MDR cells. However, SP600125, a JNK inhibitor had no effect in combination with Doc or DOX (Figure 5B). Hence, we showed that p38 MAPK promotes P-gpmediated MDR. SB203580 also enhanced Doc-induced apoptosis in MDR cancer cells (Figure 5D). These results demonstrate that the $\mathrm{p} 38$ MAPK pathway enhances P-gp levels in MCF-7/MDR and K562/MDR cells.

P-gp stability is correlated with the activator protein-1 (AP-1) transcription factor [52], which is targeted by MAPK signaling pathways [53]. Human MDR1 promoter contains an AP-1-binding site [54], and increased AP-1 binding has been observed in several multidrug-resistant cell lines [55], whereas, reduced AP-1 binding has been associated with increased drug sensitivity

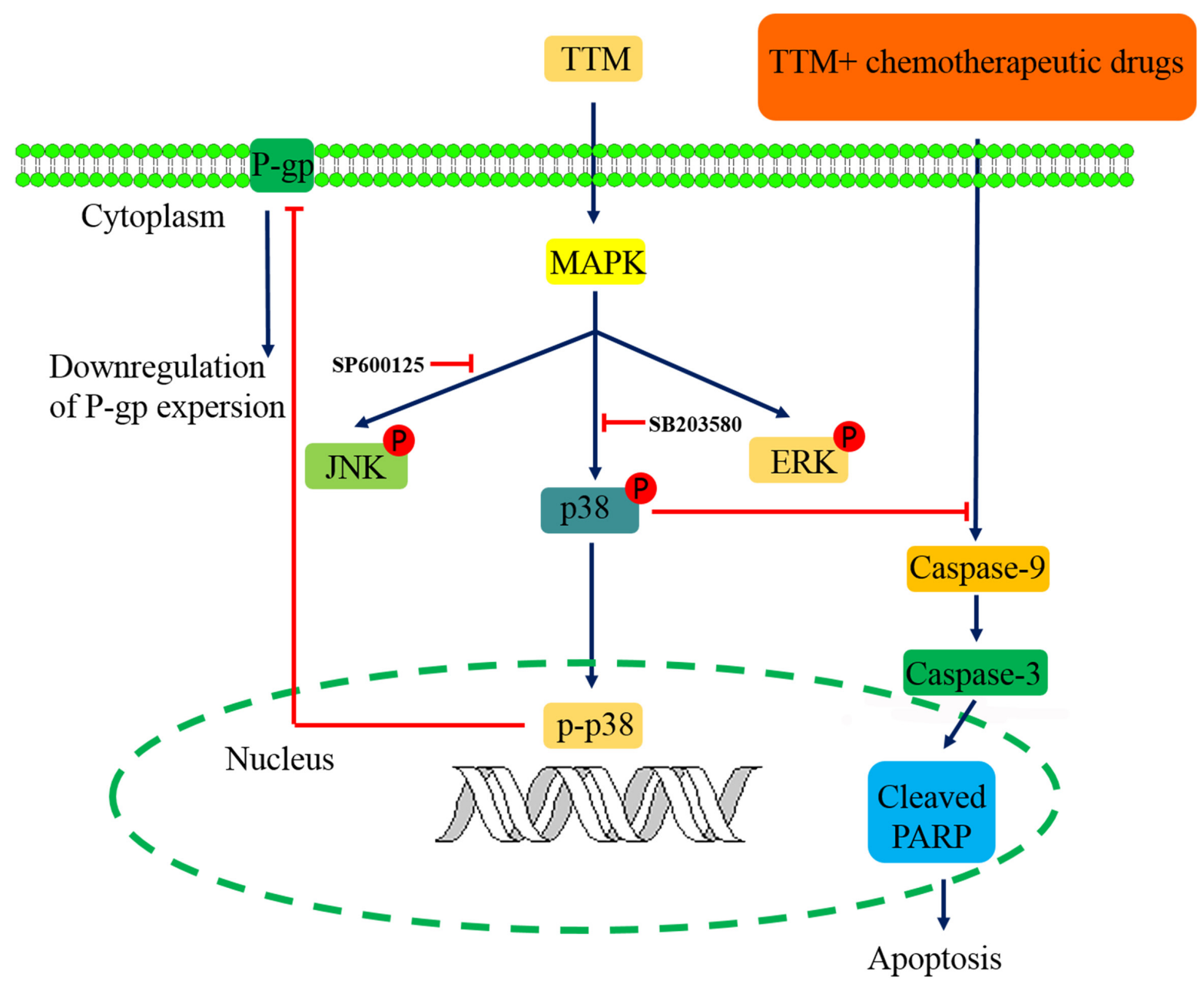

Figure 7: Schematic diagram of TTM-modulated signaling pathways that reverse multidrug resistance in MCF-7/ MDR and K562/MDR cells. 
in other cancer cell lines $[56,57]$. SB203580 has been shown to block c-Fos and c-Jun expression in response to UV irradiation and anisomycin [58]. Although p38 MAPK does not directly phosphorylate or activate c-Jun, several lines of evidence support the idea that p38 MAPK contributes to c-Jun induction via AP-1, which binds in the c-Jun promoter $[59,60]$. In addition to AP-1, c-Jun gene expression is regulated by MEF2 family of transcription factors [61]. MEF2 is essential for LPS induction of c-Jun in macrophages, which also requires functional p38 MAPK and MEF2C transcriptional factor. Furthermore, MEF2C is directly phosphorylated and activated by p38 MAPK [62]. Thus, p38 MAPK can potentially modulate c-Jun transcriptional activity by regulating AP1 and MEF2 transcription factors that have binding sites in $c-J u n$. We postulate that cJun may be intrinsically involved in p38 MAPK mediated P-gp expression.

It is also worth noting that SB203580 showed more cytotoxicity than TTM due to induction of karyopyknosis induction (data not shown) and lower $\mathrm{IC}_{50}$ values in our models (Figure 1D-1F, and Supplementary Figure 6). We further demonstrated that p38 overexpression parental MCF-7 and K562 cells increased P-gp levels by enhancing phospho-p38 MAPK levels. Thus, higher p38 MAPK levels decreased efficacy of TTM-mediated P-gp downregulation (Figure 6A and Supplementary Figure 7). Moreover, higher p38 MAPK levels decreased intracellular DOX and Rh123 levels in presence of TTM (Figure 6B).

In conclusion, TTM, a novel syncarpic acidconjugated monoterpene, increases cytotoxicity of chemotherapeutic drugs in MDR cancer cells by decreasing P-gp expression via p38 MAPK inhibition (Figure 7). Thus, our study demonstrates that TTM is a potential therapeutic drug for cancer patients demonstrating multi-drug resistance.

\section{MATERIALS AND METHODS}

\section{Isolation and identification of TTM from Rhodomyrtus tomentosa}

TTM was isolated from the petroleum ether soluble fraction of $95 \%$ ethanol extract of the leaves of Rhodomyrtus tomentosa through various chromatographic techniques including column chromatography over silica gel, ODS, Sephadex LH-20 and preparative HPLC. The structure was elucidated as a novel syncarpic acidconjugated monoterpenoid by a comprehensive analysis of the spectral data (IR, UV, HRESIMS, ECD, 1Dand 2D-NMR). The detailed isolation and structural elucidation are shown in the latest article [63].

\section{Materials}

DOX was purchased from Santa Cruz Biotechnology (Santa Cruz, CA). DNR and EPI were purchased from
National Institutes for Food and Drug Control (Beijing, China). Doc was from ApexBio (Houston, USA). DDP, Ver, MTT, Rh123, paraformaldehyde, bovine serum albumin (BSA), Tris, dimethylsulfoxide (DMSO), $\mathrm{NaCl}$, EDTA, PMSF, SDS, and DTT were purchased from Sigma-Aldrich (St. Louis, MO). Opti-MEM and fetal bovine serum (FBS) were purchased from Life Technologies (Grand Island, NY). The annexin V-FITC/ propidium iodide (AV-FITC/PI) apoptosis detection kit was purchased from Miltenyi Biotec (Shanghai, China).

The pMT3 p38 plasmid was a gift from John Kyriakis (Addgene plasmid \# 12658). The MDR1 plasmid was purchased from Genscript (Nanjing, China). The proteasome inhibitor SB203580 and SP600125 were purchased from MedChem Express (MCE, Shanghai, China). The primary antibodies for P-gp, p38, p-p38, p-JNK, p-ERK, PARP, cleaved-PARP, Caspase-9, cleavedCaspase-9, Caspase-3, cleaved-Caspase-3 and GAPDH were purchased from Cell Signaling Technology (CST, Danvers, MA). Goat anti-rabbit and goat anti-rabbit IgG Fab2 Alexa Fluor (R) antibodies (CST) were used as secondary antibodies. TTM was reserved in DMSO at the concentration of $50 \mathrm{mM}$. CCK-8 solution was purchased from qcbio Science \& Technologies (Shanghai, China)

\section{Cell lines and cell culture}

Parental sensitive human breast cancer cell line MCF-7 and multidrug resistant cell line MCF-7/MDR obtained by the Institute of Hematology and Blood Diseases Hospital (Tianjin, China) were used as an experimental model. Human leukemia cell line K562 and its Doxorubicin-selected P-gp-overexpressing K562/ MDR cells were purchased from the KeyGEN BioTECH (Nanjing, China). Both, sensitive and resistant cells were grown in RPMI-1640 medium supplemented with $10 \%$ fetal bovine serum at $37{ }^{\circ} \mathrm{C}$ with $5 \% \mathrm{CO}_{2}$ incubator. DOX $(1.0 \mu \mathrm{M})$ was added to the culture medium to maintain the MDR characteristics of the MCF-7/MDR cells and K562/ MDR cells [64].

\section{Cell viability assays}

\section{MTT assay}

Cell proliferation was assessed by MTT colorimetric assay. Briefly, MCF-7, MCF-7/MDR and MCF-10A cells were seeded in 96-well plates at a density of $5 \times 10^{3}$ cells per well and incubated over-night to permit cell adhesion to the cell dishes. Then, the cells were treated with various concentrations of DOX, DNR, EPI, Doc and DDP in the presence or absence of TTM or Ver for $48 \mathrm{hr} .20 \mu \mathrm{L}$ MTT solution was then added to each well followed incubation for an additional $4 \mathrm{hr}$. Finally, the purple formazan crystals formed were dissolved in $150 \mu \mathrm{L}$ of DMSO by gently shaking for 10 mins. The absorbance was evaluated at a test wavelength of $570 \mathrm{~nm}$, and a 
reference wavelength of $630 \mathrm{~nm}$ by ELISA reader (Spectra Max Plus384; Molecular Devices, Sunnyvale, CA). The concentration required to inhibit cell growth by $50 \%\left(\mathrm{IC}_{50}\right)$ was calculated by using GraphPad Prism 5.0. Cell viability was calculated using the following formula:

$$
\text { Cell viability }=(\mathrm{At} / \mathrm{As}) \times 100 \%
$$

At and As represent the absorbance of the test substances and solvent control, respectively [65].

The resistance index (RI) was calculated using the following formula: $[28,66]$ resistance index $(\mathrm{RI})=\mathrm{IC}_{50}$ (MDR cells) / $\mathrm{IC}_{50}$ (their parental sensitive cells). The reversal fold change, in terms of potency of reversal, was calculated using the following formula: reversal fold change $(\mathrm{RF})=\mathrm{IC}_{50}$ (MDR cells) $/ \mathrm{IC}_{50}$ (MDR cells combined with TTM or Ver treatment).

To measure the inhibitory effect of TTM on p38MAPK signaling, MCF-7 or MCF-7/MDR cells were treated with serial dilutions of Doc with or without $10 \mu \mathrm{M}$ SB203580 or $30 \mu \mathrm{M}$ TTM and/or $10 \mu \mathrm{M}$ SP600125 for 48 $\mathrm{hr}$, followed by the MTT assay.

All experiments were conducted in triplicate and repeated more than three times. Ver was used as a positive control.

\section{CCK-8 assay}

K562 and K562/MDR cells were seeded in 96-well plates with a density of $5 \times 10^{3}$ cells/well in RPMI-1640 containing $10 \%$ FBS. Then the cells were separately exposed to a series of concentrations of compounds complexes for $48 \mathrm{hr}$ and were added to a volume of $100 \mu \mathrm{L}$. After $48 \mathrm{hr}$ incubation, $10 \mu \mathrm{L}$ of the CCK-8 was dropped into each well to culture for $4 \mathrm{hr}$. The cell viabilities were monitored through measurement of the absorbance at $450 \mathrm{~nm}$ on an ELISA reader. The stimulation index (SI) was calculated based on the following formula [67]: $\mathrm{SI}=\left(\mathrm{OD}_{\mathrm{tc}}-\mathrm{OD}_{\mathrm{bl}}\right) /\left(\mathrm{OD}_{\mathrm{ntc}}-\mathrm{OD}_{\mathrm{bl}}\right) \cdot\left(\mathrm{OD}_{\mathrm{tc}}\right.$ is the mean $\mathrm{OD}$ of the treated cultures, $\mathrm{OD}_{\text {ntc }}$ is the mean OD of the untreated cultures, and $\mathrm{OD}_{\mathrm{bl}}$ is the mean OD of the blank wells).

To measure the inhibitory effect of TTM on p38MAPK signaling, K562 or K562/MDR cells were treated with serial dilutions of Doc with or without $10 \mu \mathrm{M}$ SB203580 or $30 \mu \mathrm{M}$ TTM and/or $10 \mu \mathrm{M}$ SP600125 for 48 $\mathrm{hr}$, followed by the CCK-8 assay.

All experiments were conducted in triplicate and repeated more than three times. Ver was used as a positive control.

\section{Intracellular accumulation and efflux of DOX assay}

The DOX accumulation analyses were performed by fluorescence-activated cell sorter (FACS) analysis and fluorescence microscopy analysis as described previously [68]. In the accumulation assay, both MDR cells and their parent cells were pretreated with or without $10 \mu \mathrm{M}$ TTM or $10 \mu \mathrm{M}$ Ver for $4 \mathrm{hr}$ and then incubated with $10 \mu \mathrm{M}$ DOX for $3 \mathrm{hr}$. Ver $(10 \mu \mathrm{M})$ was used as a positive control. In the efflux study, sensitive cells and resistance cells were first cultured with medium containing $10 \mu \mathrm{M}$ DOX at $37^{\circ} \mathrm{C}$ for $3 \mathrm{hr}$, washed 3 times with PBS, then incubated in the absence or presence of $10 \mu \mathrm{M}$ TTM at $37^{\circ} \mathrm{C}$ for another $4 \mathrm{hr}$ (or with $10 \mu \mathrm{M}$ Ver as a positive control). After incubation, all cells were washed twice with icecold PBS and subjected to BD Accuri C6 flow cytometry (Becton \& Dickinson Company, Franklin Lakes, NJ) to detect the fluorescence produced by DOX for efflux analysis.

\section{Rh123 flow cytometry assay}

The function of P-gp was evaluated by examining the intracellular accumulation and efflux of Rh123 as previously described $[68,69]$. In the accumulation analysis, MDR cells and their parent cells were treated with or without 10,30 or $50 \mu \mathrm{M}$ TTM or $10 \mu \mathrm{M}$ Ver for $1.5 \mathrm{hr}$ and then incubated with $5 \mu \mathrm{M} \mathrm{Rh} 123$ at $37^{\circ} \mathrm{C}$ for $1.5 \mathrm{hr}$. In the efflux study, MDR cells and their parent cells were first cultured with medium containing $5 \mu \mathrm{M}$ Rh123 in the dark for $1.5 \mathrm{hr}$, washed 2 times with PBS, then incubated in the absence or presence of 10,30 or $50 \mu \mathrm{M}$ TTM at $37{ }^{\circ} \mathrm{C}$ for additional $1.5 \mathrm{hr}$ (or with 10 $\mu \mathrm{M}$ Ver as a positive control). Subsequently, the culture medium was removed and cells were washed two times with PBS. Finally, the cells were suspended into $250 \mu \mathrm{L}$ PBS followed by FACS to examine green fluorescence produced.

\section{The laser confocal to examine the accumulation of Rh123 on MDR cells}

To further visualize the effect of TTM on the intracellular retention of Rh123, $5 \times 10^{3}$ cells per well were seeded in the 96-well plate for overnight. The cells were treated with TTM $(10,30 \mu \mathrm{M})$ for $48 \mathrm{hr}$, and were then incubated with $10 \mu \mathrm{M}$ Rh123 alone or $10 \mu \mathrm{M}$ Rh123 combination with TTM in the fresh RPMI 1640 medium for $1.5 \mathrm{hr}$ in darkness at $37{ }^{\circ} \mathrm{C}$. After that cells were washed 3 times with cold PBS and images were acquired by the laser confocal.

\section{Apoptosis assay}

Apoptosis was evaluated by FACS consistent with the manufacturer's instructions. Sensitive cells and MDR cells were treated with (+) or without (-) $30 \mu \mathrm{M}$ TTM combined with $1.0 \mu \mathrm{M}$ Doc for $48 \mathrm{hr}$. Cells were then washed twice with cold PBS, suspended in $100 \mu \mathrm{L}$ of binding buffer at a concentration of $1 \times 10^{6}$ cells $/ \mathrm{mL}$. After that, cells were incubated with fluorescein isothicocyannte (FITC)-conjugated annexin V reagent and PI in binging 
buffer for 30 mins at room temperature as described by the manufacture and finally determined by FACS.

\section{Colony formation assays}

MCF-7 and MCF-7/MDR cells were plated on 6-well plates at a density of eight hundred cells per well. Following incubation overnight, the cells were treated with TTM $(10 \mu \mathrm{M})$ with or without Doc. The medium was replaced after $48 \mathrm{hr}$ of incubation, and the colonies were further observed 15 days later. The plates were then stained with crystal violet solution (Sigma-Aldrich, St. Louis, MO), and the photographs of the colonies were taken manually [70].

\section{Plasmid transfection assay}

Plasmid preparation was performed and as previously described with some modifications [71, 72]. MCF-7 cells and K562 cells were washed twice with OptiMEM (Life Technologies, Grand Island, NY). Cells were then transfected with plasmid using Opti-MEM containing $10 \mu \mathrm{g}$ plasmids in $100 \mu \mathrm{L}$ of Opti-MEM and Super Electroporator NEPA21 system (NEPAGENE, Japan). After that cells were plated on 6-well plates at a density of $1 \times 10^{6}$ cells cells per well. Twenty-four hours after transfection, cells were treated with $30 \mu \mathrm{M}$ TTM for $48 \mathrm{hr}$ prior to harvesting.

\section{Overexpression of P-gp and p38 in MCF-7 and K562 cells}

Transfection was performed using the Super Electroporator NEPA21 system. In brief, $1 \times 10^{6}$ cells were transfected using Opti-MEM containing $10 \mu \mathrm{g}$ plasmid. MCF-7 cells and K562 cells were transfected with the MDR1 plasmid, p38 plasmid or their mock plasmids for $24 \mathrm{hr}$, and treated with or without $30 \mu \mathrm{M}$ TTM for another $48 \mathrm{hr}$, followed by Western blot analysis.

\section{Quantitative real-time RT-PCR}

The qRT-PCR was performed as previously described [73]. The $\Delta$ cycle threshold method was used for the calculation of relative differences in mRNA abundance with a LightCycler 480 (Roche Molecular Biochemicals, Mannheim, Germany). Data were normalized to the expression of GAPDH. The results were expressed as fold-changes. The normalized value of the target mRNA of the control group is arbitrarily presented as 1. The sequences of primers used were as follows: MDR1, 5'-CAGAGTCAAGGAGCATGGCA-3' (sense) and 5'-TCAGAGTTCACTGGCGTTT-3' (antisense); MRP1, 5'-ATGGCTCCGACCCGCT-3' (sense) and 5'-AGAGGTAAAAACAAGGCACCCA-3' (antisense); BCRP, 5'-GCACATGCTTGGTGGTCTTG-3' (sense) and 5'-GGCTCAGGATCTCAGGATGC-3' (antisense); and
GAPDH, 5'-GAAAGCCTGCCGGTGACTAA-3' (sense) and 5'-AGGAAAAGCATCACCCGGAG-3' (antisense).

\section{Western blot analysis}

Western blot analysis was performed as previously described [72]. MDR cells and their corresponding parental cells were incubated with various concentrations of TTM or $0.1 \%$ DMSO for $48 \mathrm{hr}$. Harvesting after trypsinisation, cells were treated with $1 \times$ RIPA lysis buffer (50 mM Tris-HCl, pH 7.4, $150 \mathrm{mM} \mathrm{NaCl}, 0.25 \%$ deoxycholic acid, 1\% NP-40, $1 \mathrm{mM}$ EDTA and protease inhibitors) (Amresco, Solon, USA) to extract the total proteins. An aliquot of proteins from the total cell lysates (30 to $40 \mu \mathrm{g} /$ lane) was separated by sodium dodecyl sulfate $(8 \%, 12 \%$ or $15 \%)$ polyacrylamide gelelectrophoresis (SDS-PAGE, BioRad Laboratories, Hercules, CA), wet-transferred to NC membrane (BioRad Laboratories, Hercules, CA) and blotted with primary antibodies specific for Cleaved Caspase-3, Caspase-3, Caspase-9, Cleaved Caspase-9, PARP, Cleaved PARP, P-gp, Phospho-p44/42 MAPK, Phospho-p38 MAPK, Phospho-SAPK/JNK, p38 MAP Kinase, GAPDH, probed with secondary isotype specific antibodies tagged with horseradish peroxidase (Cell Signaling Technology). Bound immuno-complexes were detected using ChemiDOC ${ }^{\text {TM }}$ XRS+system (BioRad Laboratories, Hercules, CA).

\section{The laser confocal to detect the levels of P-gp on the cell membrane}

Immunofluorescence was done as previously described before [74]. MCF-7 cells and MCF-7/MDR were cultured on a 96 wells glass culture plate. Cells were treated with TTM for $48 \mathrm{hr}$. The cells were fixed with warm $4 \%$ paraformaldehyde for 15 mins at room temperature. Then abandon the fixed liquid, washed 2 times with PBS for each 5mins and blocked with 5\% BSA for $1 \mathrm{hr}$. Incubation with primary antibodies against P-gp was performed overnight at $4{ }^{\circ} \mathrm{C}$. After incubation, washed 2 times with PBS for each 5 mins. The cells were then incubated with Alexa Flour 488-conjugated secondary antibody for $2 \mathrm{hr}$ at room temperature in the dark. After incubation, washed 2 times with PBS for each 5 mins. The nuclei were stained with DAPI (Beyotime, Haimen, China) for 10 mins before imaging. Images were taken by ImageXpress ${ }^{\mathbb{R}}$ Micro Confocal (Molecular Devices, USA).

\section{Statistical analysis}

For all experiments, quantitative results were reported as "mean \pm SEM" values from at least three experiments performed in a parallel manner. Statistical analysis was performed with the GraphPad Prism 5 software. One-way ANOVA was used to compare each parameter. Next, unpaired, two tailed student's $t$ test was 
performed to identify which group differences accounted for significant overall ANOVA results. ${ }^{*}$ denotes $P<0.05$, ** or \#\# denotes $P<0.01$ and ${ }^{* * *}$ or $\# \#$ denotes $P<0.001$ was considered as significant.

\section{Abbreviations}

ABC: ATP-binding cassette; AV-FITC/PI: annexin V-FITC/propidium iodide; BSA: bovine serum albumin; CST: Cell Signaling Technology; DDP: cisplatin; DMSO: dimethylsulfoxide; DNR: daunorubicin; Doc: docetaxel; DOX: doxorubicin; EPI: epirubicin; FACS: fluorescenceactivated cell sorter; FBS: fetal bovine serum; FITC: fluorescein isothicocyannte; MDR: multidrug resistance; P-gp: P-glycoprotein; qRT-PCR: quantitative real-time polymerase chain reaction; RF: reversal fold change; Rh123: rhodamine 123; RI: resistance index; SDS-PAGE: sodium dodecyl sulfate polyacrylamide gelelectrophoresis; SI: stimulation index; TTM: tomentodione M; Ver: verapamil.

\section{Author contributions}

$\mathrm{XZ}$ designed, performed and analyzed experiments, and drafted the article. YX contributed to the conception, data analysis, design of the study and revised the manuscript. YZ and JL isolated and purified the compound TTM, and collected relevant data. $\mathrm{CH}, \mathrm{HZ}$ and $\mathrm{CZ}$ analyzed and interpreted of data, and revised the manuscript. LY and LK revised the manuscript and finally approved of the version to be published. All authors read and approved the final manuscript.

\section{CONFLICTS OF INTEREST}

The authors declare that there are no conflicts of interest.

\section{FUNDING}

Funding was provided by the Natural Science Foundation of Jiangsu Province (BK20160763), the National Natural Science Foundation of China (Program No. 81703754, 81503211 and 81673554), the Project Funded by the Priority Academic Program Development of Jiangsu Higher Education Institutions (PAPD) and the Program for Changjiang Scholars and Innovative Research Team in University (PCSIRT-IRT1193).

\section{REFERENCES}

1. Kasaian J, Mosaffa F, Behravan J, Masullo M, Piacente S, Ghandadi M, Iranshahi M. Reversal of P-glycoproteinmediated multidrug resistance in MCF-7/Adr cancer cells by sesquiterpene coumarins. Fitoterapia. 2015; 103: 149-54. https://doi.org/10.1016/j.fitote.2015.03.025.
2. Wijdeven RH, Pang B, Assaraf YG, Neefjes J. Old drugs, novel ways out: drug resistance toward cytotoxic chemotherapeutics. Drug Resistance Updates. 2016; 28: 65-81. https://doi.org/10.1016/j.drup.2016.07.001.

3. Borst P, Elferink RO. Mammalian ABC transporters in health and disease. Annu Rev Biochem. 2002; 71: 537-92. https:// doi.org/10.1146/annurev.biochem.71.102301.093055.

4. Imai Y, Ishikawa E, Asada S, Sugimoto Y. Estrogenmediated post transcriptional down-regulation of breast cancer resistance protein/ABCG2. Cancer Research. 2005; 65: 596. https://doi.org/10.1158/0008-5472.CAN-05-1894.

5. Katayama K, Yoshioka S, Tsukahara S, Mitsuhashi J, Sugimoto Y. Inhibition of the mitogen-activated protein kinase pathway results in the down-regulation of P-glycoprotein. Molecular cancer therapeutics. 2007; 6: 2092102. https://doi.org/10.1158/1535-7163.MCT-07-0148.

6. Oram JF, Lawn RM. ABCA1. The gatekeeper for eliminating excess tissue cholesterol. Journal of Lipid Research. 2001; 42: 1173-9.

7. Spolitu S, Uda S, Deligia S, Frau A, Collu M, Angius F, Batetta B. Multidrug resistance P-glycoprotein dampens SR-BI cholesteryl ester uptake from high density lipoproteins in human leukemia cells. American Journal of Cancer Research. 2016; 6: 615.

8. Luker GD, Nilsson KR, Covey DF, Piwnica-Worms D. Multidrug resistance (MDR1) P-glycoprotein enhances esterification of plasma membrane cholesterol. Journal of Biological Chemistry. 1999; 274: 6979-91. https://doi. org/10.1074/jbc.274.11.6979.

9. Mutoh K, Tsukahara S, Mitsuhashi J, Katayama K, Sugimoto Y. Estrogen-mediated post transcriptional downregulation of P-glycoprotein in MDR1-transduced human breast cancer cells. Cancer Science. 2006; 97: 1198. https:// doi.org/10.1111/j.1349-7006.2006.00300.x.

10. Xia YZ, Yang L, Xue GM, Zhang C, Guo C, Yang YW, Li SS, Zhang LY, Guo QL, Kong LY. Combining GRP78 suppression and MK2206-induced Akt inhibition decreases doxorubicin-induced P-glycoprotein expression and mitigates chemoresistance in human osteosarcoma. Oncotarget. 2016; 7: 56371-82. https://doi.org/10.18632/ oncotarget. 10890.

11. Efferth T, Osieka R. Clinical relevance of the MDR-1 gene and its gene product, P-glycoprotein, for cancer chemotherapy: A meta-analysis. 1993.

12. Efferth T, Volm M. Multiple resistance to carcinogens and xenobiotics: P-glycoproteins as universal detoxifiers. Archives of Toxicology. 2017; 91: 1-24. doi: 10.1007/ s00204-017-1938-5.

13. Ravindranath AK, Kaur S, Wernyj RP, Kumaran MN, Miletti-Gonzalez KE, Chan R, Lim E, Madura K, Rodriguez-Rodriguez L. CD44 promotes multi-drug resistance by protecting P-glycoprotein from FBXO21mediated ubiquitination. Oncotarget. 2015; 6: 26308. https://doi.org/10.18632/oncotarget.4763. 
14. Harazono Y, Kho DH, Balan V, Nakajima K, Hogan V, Raz A. Extracellular galectin-3 programs multidrug resistance through $\mathrm{Na}+/ \mathrm{K}+-$ ATPase and P-glycoprotein signaling. Oncotarget. 2015; 6: 19592. https://doi.org/10.18632/ oncotarget.4285.

15. Baldini N, Scotlandi K, Barbanti-Bròdano G, Manara MC, Maurici D, Bacci G, Bertoni F, Picci P, Sottili S, Campanacci M. Expression of P-glycoprotein in highgrade osteosarcomas in relation to clinical outcome. New England Journal of Medicine. 1995; 333: 1380-5. https:// doi.org/10.1056/NEJM199511233332103.

16. Yuen AR, Sikic BI. Multidrug resistance in lymphomas. Journal of clinical oncology. 1994; 12: 2453-9. https://doi. org/10.1200/JCO.1994.12.11.2453.

17. Hsia T, Lin C, Wang J, Ho S, Kao A. Relationship between chemotherapy response of small cell lung cancer and P-glycoprotein or multidrug resistance-related protein expression. Lung. 2002; 180: 173-9. https://doi. org/10.1007/s004080000091.

18. Burger H, Foekens JA, Look MP, Meijer-van Gelder ME, Klijn JG, Wiemer EA, Stoter G, Nooter K. RNA expression of breast cancer resistance protein, lung resistance-related protein, multidrug resistance-associated proteins 1 and 2, and multidrug resistance gene 1 in breast cancer. Clinical Cancer Research. 2003; 9: 827-36.

19. Marie JP, Zittoun R, Sikic BI. Multidrug resistance (mdr1) gene expression in adult acute leukemias: correlations with treatment outcome and in vitro drug sensitivity. Blood. 1991; 78: 586-92.

20. Fletcher JI, Haber M, Henderson MJ, Norris MD. ABC transporters in cancer: more than just drug efflux pumps. Nature Reviews Cancer. 2010; 10: 147-56. https:/doi. org/10.1038/nrc2789.

21. Friedenberg WR, Rue M, Blood EA, Dalton WS, Shustik C, Larson RA, Sonneveld P, Greipp PR. Phase III study of PSC-833 (valspodar) in combination with vincristine, doxorubicin, and dexamethasone (valspodar/VAD) versus VAD alone in patients with recurring or refractory multiple myeloma (E1A95). Cancer. 2006; 106: 830-8. https://doi. org/10.1002/cncr.21666.

22. Diéras V, Bonneterre J, Laurence V, Degardin M, Pierga JY, Bonneterre ME, Marreaud S, Lacombe D, Fumoleau P. Phase I combining a P-glycoprotein inhibitor, MS209, in combination with docetaxel in patients with advanced malignancies. Clinical cancer research. 2005; 11: 6256-60. https://doi.org/10.1158/1078-0432.Ccr-04-2316.

23. Ludwig JA, Szakács G, Martin SE, Chu BF, Cardarelli C, Sauna ZE, Caplen NJ, Fales HM, Ambudkar SV, Weinstein JN. Selective toxicity of NSC73306 in MDR1-positive cells as a new strategy to circumvent multidrug resistance in cancer. Cancer research. 2006; 66: 4808-15. https://doi. org/10.1158/0008-5472.Can-05-3322.

24. Hyafil F, Vergely C, Vignaud PD, Grandperret T. In Vitro and in Vivo Reversal of Multidrug Resistance by GF120918, an Acridonecarboxamide Derivative. Cancer Research. 1993; 53: 4595-602.

25. Orlowski S, Mir LM, Jr BJ, Garrigos M. Effects of steroids and verapamil on P-glycoprotein ATPase activity: progesterone, desoxycorticosterone, corticosterone and verapamil are mutually non-exclusive modulators. Biochemical Journal. 1996; 317: 515-22. https://doi. org/10.1042/bj3170515.

26. Krishna R, Mayer LD. Multidrug resistance (MDR) in cancer - Mechanisms, reversal using modulators of MDR and the role of MDR modulators in influencing the pharmacokinetics of anticancer drugs. European Journal of Pharmaceutical Sciences. 2000; 11: 265-83. https://doi. org/10.1016/S0928-0987(00)00114-7.

27. Robert J, Jarry C. Multidrug resistance reversal agents. Journal of medicinal chemistry. 2003; 46: 4805-17. https:// doi.org/10.1021/jm030183a.

28. Xia Y, Ni K, Guo C, Zhang C, Geng Y, Wang Z, Yang L, Kong L. Alopecurone B reverses doxorubicin-resistant human osteosarcoma cell line by inhibiting P-glycoprotein and NF-kappa B signaling. Phytomedicine. 2015; 22: 34451. https://doi.org/10.1016/j.phymed.2014.12.011.

29. Yuan W, Zhang R, Wang J, Ma Y, Li W, Jiang R, Cai S. Asclepiasterol, a novel $\mathrm{C} 21$ steroidal glycoside derived from Asclepias curassavica, reverses tumor multidrug resistance by down-regulating P-glycoprotein expression. Oncotarget. 2016; 7: 31466. https://doi.org/10.18632/oncotarget.8965.

30. Paterna A, Kincses A, Spengler G, Mulhovo S, Molnár J, Ferreira MU. Dregamine and tabernaemontanine derivatives as ABCB1 modulators on resistant cancer cells. European Journal of Medicinal Chemistry. 2017; 128: 247. https:// doi.org/10.1016/j.ejmech.2017.01.044.

31. Zhang Y, An FL, Huang SS, Yang L, Gu YC, Luo J, Kong LY. Diverse tritepenoids from the fruits of Walsura robusta and their reversal of multidrug resistance phenotype in human breast cancer cells. Phytochemistry. 2017; 136: 10818. https://doi.org/10.1016/j.phytochem.2017.01.008.

32. Borst P, Evers R, Kool M, Wijnholds J. A family of drug transporters: the multidrug resistance-associated proteins. J Natl Cancer Inst. 2000; 92: 1295-302. https://doi. org/10.1093/jnci/92.16.1295.

33. Wijdeven RH, Pang B, Assaraf YG, Neefjes J. Old drugs, novel ways out: Drug resistance toward cytotoxic chemotherapeutics. Drug Resist Updat. 2016; 28: 65-81. https://doi.org/10.1016/j.drup.2016.07.001.

34. Szakács G, Paterson JK, Ludwig JA, Boothgenthe C, Gottesman MM. Targeting multidrug resistance in cancer. Nature Reviews Drug Discovery. 2006; 5: 219-34. https:// doi.org/10.1038/nrd1984.

35. Tsou S, Chen T, Hsiao H, Chen Y. A critical dose of doxorubicin is required to alter the gene expression profiles in MCF-7 cells acquiring multidrug resistance. PloS one. 2015; 10: e0116747. https://doi.org/10.1371/journal. pone. 0116747 . 
36. Zhang J, Lin M, Yi T, Tang Y, Fan L, He X, Zhao Z, Chen H. Apoptosis sensitization by Euphorbia factor L1 in ABCB1-mediated multidrug resistant K562/ADR cells. Molecules. 2013; 18: 12793-808. https://doi.org/10.3390/ molecules 181012793 .

37. Chiu L, Ko J, Lee Y, Yang T, Tee Y, Sheu G. L-type calcium channel blockers reverse docetaxel and vincristine-induced multidrug resistance independent of $\mathrm{ABCB} 1$ expression in human lung cancer cell lines. Toxicology Letters. 2010; 192: 408-18. https://doi.org/10.1016/j.toxlet.2009.11.018.

38. Amirikordestani L, Basseville A, Kurdziel K, Fojo AT, Bates SE. Targeting MDR in Breast and Lung Cancer: Discriminating its Potential Importance from the Failure of Drug Resistance Reversal Studies. Drug Resistance Updates Reviews \& Commentaries in Antimicrobial \& Anticancer Chemotherapy. 2012; 15: 50. https://doi.org/10.1016/j. drup.2012.02.002.

39. Xu L, Feng JM, Li JX, Zhu JM, Song SS, Tong LJ, Chen Y, Yang XY, Shen YY, Lian FL. Tanshinone-1 induces tumor cell killing, enhanced by inhibition of secondary activation of signaling networks. Cell Death \& Disease. 2013; 4: e905. https://doi.org/10.1038/cddis.2013.443.

40. Zhang L, Wang K, Lei Y, Li Q, Nice EC, Huang C. Redox signaling: Potential arbitrator of autophagy and apoptosis in therapeutic response. Free Radical Biology \& Medicine. 2015; 89: 452. https://doi.org/10.1016/j. freeradbiomed.2015.08.030.

41. Sun M, Yang C, Zheng J, Wang M, Chen M, Le DQS, Kjems J, Bünger CE. Enhanced efficacy of chemotherapy for breast cancer stem cells by simultaneous suppression of multidrug resistance and antiapoptotic cellular defense. Acta biomaterialia. 2015; 28: 171-82. https://doi.org/10.1016/j. actbio.2015.09.029.

42. Franqui-Machin R, Wendlandt EB, Janz S, Zhan F, Tricot G. Cancer stem cells are the cause of drug resistance in multiple myeloma: fact or fiction? Oncotarget. 2015; 6: 40496. https://doi.org/10.18632/oncotarget.5800.

43. Yang L, Wei D, Chen Z, Wang J, Kong L. Reversal of multidrug resistance in human breast cancer cells by Curcuma wenyujin and Chrysanthemum indicum. Phytomedicine. 2011; 18: 710-8. https://doi.org/10.1016/j. phymed.2010.11.017.

44. Jin W, Lu Y, Li Q, Wang J, Zhang H, Chang G, Lin Y, Pang T. Down-regulation of the P-glycoprotein relevant for multidrug resistance by intracellular acidification through the crosstalk of MAPK signaling pathways. The international journal of biochemistry \& cell biology. 2014; 54: 111-21. https://doi.org/10.1016/j.biocel.2014.06.016.

45. Peck RA, Hewett J, Harding MW, Wang YM, Chaturvedi PR, Bhatnagar A, Ziessman H, Atkins F, Hawkins MJ. Phase I and pharmacokinetic study of the novel MDR1 and MRP1 inhibitor biricodar administered alone and in combination with doxorubicin. Journal of clinical oncology. 2001; 19: 3130-41. https://doi.org/10.1200/JCO.2001.19.12.3130.
46. Jian K, Zhang C, Shang Z, Yang L, Kong L. Eucalrobusone $\mathrm{C}$ suppresses cell proliferation and induces ROS-dependent mitochondrial apoptosis via the p38 MAPK pathway in hepatocellular carcinoma cells. Phytomedicine. 2016; 25: 71-82. https://doi.org/10.1016/j.phymed.2016.12.014.

47. Eichhorn T, Efferth T. P-glycoprotein and its inhibition in tumors by phytochemicals derived from Chinese herbs. Journal of ethnopharmacology. 2012; 141: 557-70. https:// doi.org/10.1016/j.jep.2011.08.053.

48. Johnstone RW, Ruefli AA, Lowe SW. Apoptosis: a link between cancer genetics and chemotherapy. Cell. 2002; 108: 153-64. https://doi.org/10.1016/S0092-8674(02)00625-6.

49. Lei Z, Zhang Z, Fan C, Chen Y, Lin Y, Jing W. Aromatic heterocyclic esters of podophyllotoxin exert anti-MDR activity in human leukemia K562/ADR cells via ROS/ MAPK signaling pathways. European Journal of Medicinal Chemistry. 2016; 123: 226-35. https://doi.org/10.1016/j. ejmech.2016.07.050.

50. Shi X, Wu S, Yang Y, Tang L, Wang Y, Dong J, Lü B, Jiang G, Zhao W. AQP5 silencing suppresses p38 MAPK signaling and improves drug resistance in colon cancer cells. Tumour Biology the Journal of the International Society for Oncodevelopmental Biology \& Medicine. 2014; 35: 7035-45. https://doi.org/10.1007/s13277-014-1956-3.

51. Cuadrado A, Nebreda Angel R. Mechanisms and functions of p38 MAPK signalling. The Biochemical journal. 2010; 429: 403. https://doi.org/10.1042/BJ20100323.

52. Guo X, Ma N, Jin W, Song J, Bu X, Yue C, Kai S, Xiong H, Jiang G, Zhang B. Increased p38-MAPK is responsible for chemotherapy resistance in human gastric cancer cells. Bmc Cancer. 2008; 8: 375. https://doi. org/10.1186/1471-2407-8-375.

53. Karin M. The Regulation of AP-1 Activity by Mitogenactivated Protein Kinases. Journal of Biological Chemistry. 1995; 270: 16483-6. https://doi.org/10.1074/ jbc.270.28.16483.

54. Ueda K, Pastan I, Gottesman MM. Isolation and sequence of the promoter region of the human multidrug-resistance (P-glycoprotein) gene. J Biol Chem. 1987; 262: 17432-6.

55. Chen TK, Smith LM, Gebhardt DK, Birrer MJ, Brown $\mathrm{PH}$. Activation and inhibition of the AP-1 complex in human breast cancer cells. Molecular Carcinogenesis. 1996; 15: 215. https://doi.org/10.1002/(SICI)10982744(199603)15:3<215::AID-MC7>3.0.CO;2-G.

56. Daschner PJ, Ciolino HP, Plouzek CA, Yeh GC. Increased AP-1 activity in drug resistant human breast cancer MCF-7 cells. Breast Cancer Res Treat. 1999; 53: 229-40. https:// doi.org/10.1023/A:1006138803392.

57. Rohlff C, Safa B, Rahman A, Chochung YS, Klecker RW, Glazer RI. Reversal of resistance to adriamycin by 8-chlorocyclic AMP in adriamycin-resistant HL-60 leukemia cells is associated with reduction of type I cyclic AMP-dependent protein kinase and cyclic AMP response element-binding 
protein DNA-binding activities. Molecular Pharmacology. 1993; 43: 372-9.

58. Hazzalin CA, Cano E, Cuenda A, Barratt MJ, Cohen P, Mahadevan LC. p38/RK is essential for stress-induced nuclear responses: JNK/SAPKs and c-Jun/ATF-2 phosphorylation are insufficient. Current Biology Cb. 1996; 6: 1028. https://doi.org/10.1016/S0960-9822(02)00649-8.

59. Humar M, Loop T, Schmidt R, Hoetzel A, Roesslein M, Andriopoulos N, Pahl HL, Geiger KK, Pannen BH. The mitogen-activated protein kinase $\mathrm{p} 38$ regulates activator protein 1 by direct phosphorylation of c-Jun. International Journal of Biochemistry \& Cell Biology. 2007; 39: 2278-88. https://doi.org/10.1016/j.biocel.2007.06.013.

60. Pramanik R, Qi X, Borowicz S, Choubey D, Schultz RM, Han J, Chen G. p38 Isoforms Have Opposite Effects on AP-1-dependent Transcription through Regulation of c-Jun THE DETERMINANT ROLE OF THE ISOFORMS IN THE p38 MAPK SIGNAL SPECIFICITY. Journal of Biological Chemistry. 2003; 278: 4831-9. https://doi. org/10.1074/jbc.M207732200.

61. Han TH, Prywes R. Regulatory role of MEF2D in serum induction of the c-jun promoter. Molecular \& Cellular Biology. 1995; 15: 2907-15. https://doi.org/10.1128/ MCB.15.6.2907.

62. Han J, Jiang Y, Li Z, Kravchenko VV, Ulevitch RJ. Activation of the transcription factor MEF2C by the MAP kinase p38 in inflammation. Nature. 1997; 386: 296. https://doi.org/10.1038/386296a0.

63. Zhang YL, Zhou XW, Wu L, Wang XB, Yang MH, Luo J, Luo JG, Kong LY. Isolation, Structure Elucidation, and Absolute Configuration of Syncarpic Acid-Conjugated Terpenoids from Rhodomyrtus tomentosa. J Nat Prod. 2017; 80: 989-98. https://doi.org/10.1021/acs.jnatprod.6b01005.

64. Kim K, Kim S, Sunnyoung YU, Park S, Choi H, Haksun YU, Jaehoon JI, Seo Y, Ahn S. Salinomycin enhances doxorubicin-induced cytotoxicity in multidrug resistant MCF-7/MDR human breast cancer cells via decreased efflux of doxorubicin. Molecular Medicine Reports. 2015; 12: 1898. https://doi.org/10.3892/mmr.2015.3633.

65. Ma T, Fan B, Zhang C, Zhao H, Han C, Gao C, Luo J, Kong L. Metabonomics applied in exploring the antitumour mechanism of physapubenolide on hepatocellular carcinoma cells by targeting glycolysis through the Akt-p53 pathway. Scientific Reports. 2016; 6: 29926. https://doi. org/10.1038/srep29926.

66. Zhao XQ, Xie JD, Chen XG, Sim HM, Zhang X, Liang YJ, Singh S, Talele TT, Sun Y, Ambudkar SV, Chen ZS, Fu LW. Neratinib reverses ATP-binding cassette B1-mediated chemotherapeutic drug resistance in vitro, in vivo, and ex vivo. Mol Pharmacol. 2012; 82: 47-58. https://doi. org/10.1124/mol.111.076299.

67. Kukhetpitakwong R, Hahnvajanawong C, Homchampa P, Leelavatcharamas V, Satra J, Khunkitti W. Immunological adjuvant activities of saponin extracts from the pods of Acacia concinna. Int Immunopharmacol. 2006; 6: 1729-35. https://doi.org/10.1016/j.intimp.2006.07.008.

68. Xue G, Xia Y, Wang Z, Li L, Luo J, Kong L. neo-Clerodane diterpenoids from Scutellaria barbata mediated inhibition of P-glycoprotein in MCF-7/ADR cells. European journal of medicinal chemistry. 2016; 121: 238-49. https://doi. org/10.1016/j.ejmech.2016.05.045.

69. Hak-Bong K, Su-Hoon L, Jee-Hyun U, Keun OW, DongWan K, Kang CD, Sun-Hee K. Sensitization of multidrugresistant human cancer cells to Hsp90 inhibitors by downregulation of SIRT1. Oncotarget. 2015; 6: 36202-18. https://doi.org/10.18632/oncotarget.5343.

70. Zhang C, Yang L, Wang X, Wang J, Yang C, Kong L. Calyxin $\mathrm{Y}$ induces hydrogen peroxide-dependent autophagy and apoptosis via JNK activation in human non-small cell lung cancer NCI-H460 cells. Cancer letters. 2013; 340: 51-62. https://doi.org/10.1016/j.canlet.2013.06.021.

71. Wang L, Meng Q, Wang C, Liu Q, Peng J, Huo X, Sun H, Ma X, Liu K. Dioscin restores the activity of the anticancer agent adriamycin in multidrug-resistant human leukemia K562/adriamycin cells by down-regulating MDR1 via a mechanism involving NF- $\kappa \mathrm{B}$ signaling inhibition. Journal of natural products. 2013; 76: 909-14. https://doi. org/10.1021/np400071c.

72. Xia Y, Yang L, Wang Z, Guo C, Zhang C, Geng Y, Kong L. Schisandrin A enhances the cytotoxicity of doxorubicin by the inhibition of nuclear factor-kappa B signaling in a doxorubicin-resistant human osteosarcoma cell line. RSC Advances. 2015; 5: 13972-84. https://doi.org/10.1039/ c4ra14324h.

73. Kim SR, Im Kim D, Kang MR, Lee KS, Park SY, Jeong JS, Lee YC. Endoplasmic reticulum stress influences bronchial asthma pathogenesis by modulating nuclear factor $\kappa \mathrm{B}$ activation. Journal of Allergy and Clinical Immunology. 2013; 132: 1397-408. e11. https://doi.org/10.1016/j. jaci.2013.08.041.

74. Fujimoto D, Ueda Y, Hirono Y, Goi T, Yamaguchi A. PAR1 participates in the ability of multidrug resistance and tumorigenesis by controlling Hippo-YAP pathway. Oncotarget. 2015; 6: 34788-99. https://doi.org/10.18632/ oncotarget. 5858 . 